Portland State University

PDXScholar

Spring 6-7-2018

\title{
Woodpeckers in the City: Habitat Use and Minimum Area Requirements of Woodpeckers in Urban Parks and Natural Areas in Portland, Oregon
}

Adam Baz

Portland State University

Follow this and additional works at: https://pdxscholar.library.pdx.edu/open_access_etds

Part of the Life Sciences Commons

Let us know how access to this document benefits you.

Recommended Citation

Baz, Adam, "Woodpeckers in the City: Habitat Use and Minimum Area Requirements of Woodpeckers in Urban Parks and Natural Areas in Portland, Oregon" (2018). Dissertations and Theses. Paper 4455. https://doi.org/10.15760/etd.6339

This Thesis is brought to you for free and open access. It has been accepted for inclusion in Dissertations and Theses by an authorized administrator of PDXScholar. Please contact us if we can make this document more accessible: pdxscholar@pdx.edu. 
Woodpeckers in the City:

Habitat Use and Minimum Area Requirements of Woodpeckers in Urban Parks and

Natural Areas in Portland, Oregon

by

Adam Baz

A thesis submitted in partial fulfillment of the

requirements for the degree of

Master of Science

in

Biology

Thesis Committee:

Michael T. Murphy, Chair

Marion Dresner

Erin Shortlidge

Joe Liebezeit

Portland State University

2018 
Urbanization has contributed to the fragmentation and alteration of natural habitats around the globe, and is rapidly increasing. In this context, forested parks play a critical role for many species by providing patches of usable habitat within the urban matrix. Such patches may be particularly valuable to forest-specialists like woodpeckers (Picidae). Yet many woodpeckers require large forest patches, which are limited in fragmented landscapes. Despite their recognized value as ecosystem engineers and keystone species, almost no research exists on woodpecker ecology or space-use in urban settings. What habitat components influence woodpecker abundance and what are their functional minimum area requirements in anthropogenic landscapes? As urban development continues to expand, it is imperative that these gaps in knowledge be filled.

I examined the habitat and area requirements of five woodpecker species in 36 forest patches throughout Portland, Oregon. Woodpeckers were surveyed over two consecutive breeding seasons (2015-2016) using point counts and audio broadcast surveys. Vegetation surveys and geospatial analysis were conducted to describe the habitat and landscape composition within and around each patch. The relationship between habitat variables and woodpecker abundance was analyzed for each species using generalized linear models. Minimum area requirements were estimated based on incidence functions plotting the probability of woodpecker occurrence in forest patches of varying size. 
Abundance of all five woodpecker species increased as a function of forest area and understory vegetation. The amount of tree cover in the landscape surrounding parks was important for the two largest species (Pileated Woodpeckers [Dryocopus pileatus] and Northern Flickers [Colaptes auratus]), although this variable influenced their abundance positively and negatively, respectively. Surprisingly, the degree of urbanization in the surrounding landscape was unrelated to woodpecker abundance for any species except Red-breasted Sapsuckers (Sphyrapicus ruber). Four of the five species I studied reached higher levels of abundance in natural areas (i.e. greenspaces with multistory vegetation) than traditional parks (i.e. parks managed for recreation, with cleared understories). I recommend that large, multistory forested parks be created and protected to benefit woodpeckers.

Minimum area requirements were generated for each species based on the forest patch size at which their predicted probability of occurrence reached 0.5 . This corresponded to an area requirement of 51 ha for Pileated Woodpeckers and 34 ha for Hairy Woodpeckers (Picoides villosus). None of the other three woodpeckers exhibited strong area-sensitivity. These findings provide much needed information on woodpecker ecology in urban landscapes, and may offer direction for park management as rates of urbanization continue to increase. 


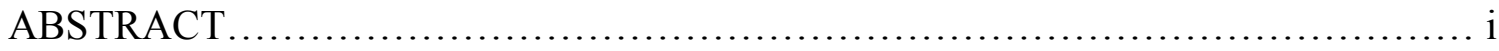

LIST OF TABLES .................................................................... iv

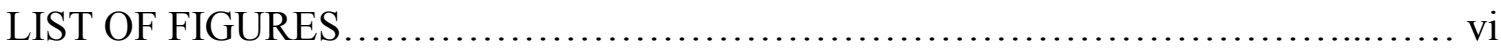

CHAPTER 1: Overview \& General Background.................................... 1

CHAPTER 2: Woodpecker Abundance \& Habitat Use in Urban Parks

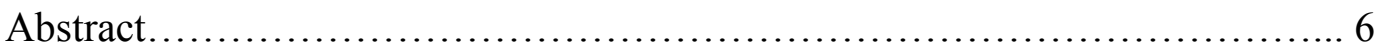

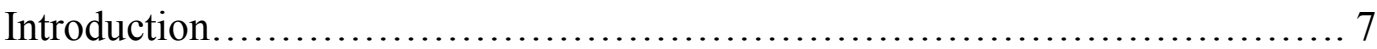

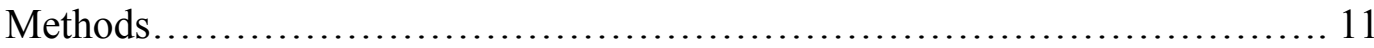

Results................................................................ 17

Discussion............................................................ 20

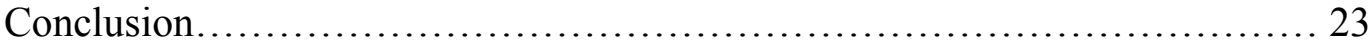

CHAPTER 3: Minimum Area Requirements of Woodpeckers in an Urban Landscape

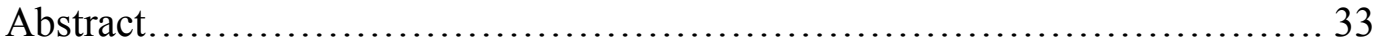

Introduction.................................................................... 34

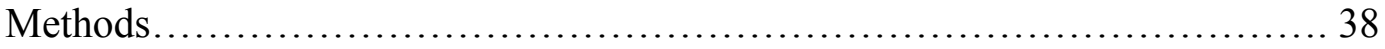

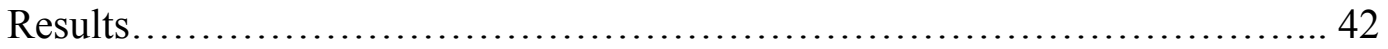

Discussion..................................................................... 44

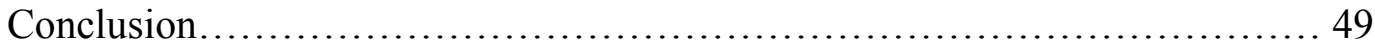

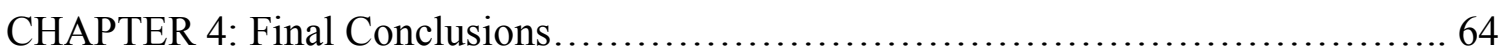

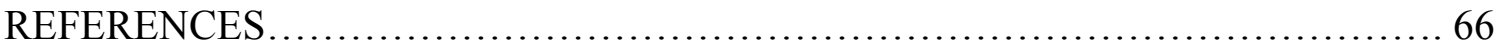




\section{LIST OF TABLES}

TABLE 2.1: Predictor variables potentially influencing woodpecker abundance in urban parks located in Portland, Oregon, and surveyed between April and June 2015 and

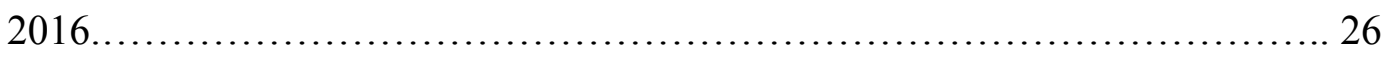

TABLE 2.2: Detections and occupancy of five woodpecker species surveyed between April and June 2015 and 2016 in parks in Portland, Oregon.................. 27

TABLE 2.3: Summary statistics of predictor variables used in the analysis of variation in woodpecker abundance among 36 parks in Portland, Oregon, surveyed between

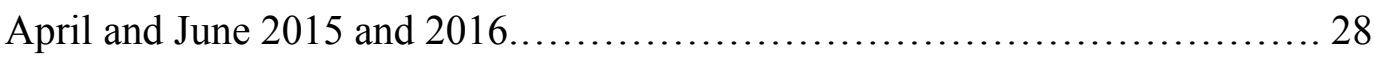

TABLE 2.4: Best generalized linear regression models describing woodpecker abundance in urban parks throughout Portland, Oregon, surveyed between April and June 2015 and 2016

TABLE 2.5: Coefficients \pm SE and ( $p$-values) from Poisson regressions describing the relationship between woodpecker abundance and a suite of biogeographic, landscape, and habitat variables in 36 parks and greenspaces in Portland, Oregon during the 2015 and 2016 breeding seasons.... 30

TABLE 3.1: Range of forest patches surveyed for woodpeckers in Portland, OR during the 2015 and 2016 breeding seasons.

TABLE 3.2: Woodpecker occurrence in 36 forest patches in Portland, OR, surveyed

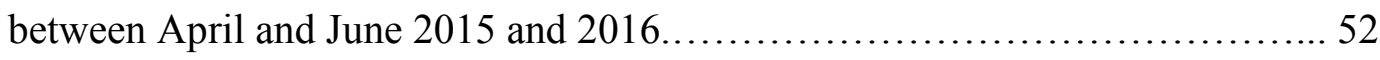


TABLE 3.3: Outputs from logistic regression models analyzing the relationship between forest patch size and woodpecker occurrence in forest fragments throughout Portland, Oregon ......................................................... 53

TABLE 3.4: Forest patch size at which the predicted probability of woodpecker occurrence reaches 0.5 and 0.75 for woodpeckers surveyed in 36 forest fragments

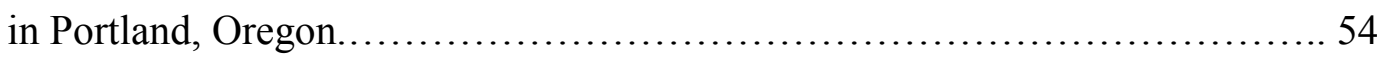

TABLE 3.5: Number of 1 ha and 10 ha forest patches that would be required to achieve the same probability of woodpecker occurrence $(P)$ as at the patch size where $P=$

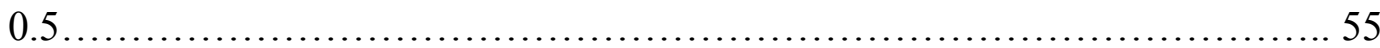




\section{LIST OF FIGURES}

FIGURE 2.1: Map of the study area in Portland, Oregon, showing the location of the 36

parks (black polygons) surveyed for woodpeckers in 2015 and 2016

FIGURE 3.1: Map of the study area showing the distribution of 36 forest patches surveyed for woodpeckers in Portland, Oregon during the 2015 and 2016 breeding seasons............................................................. 57

FIGURE 3.2: Probability of occurrence and minimum area requirements of five woodpecker species in urban forest patches in Portland, Oregon............ 58-62

FIGURE 3.3: Relationship between mean body mass and minimum area requirements based on 0.5 probability of occurrence and 0.75 probability of occurrence for five woodpecker species surveyed in forest patches throughout Portland, Oregon during the 2015 and 2016 breeding seasons........................... 63 


\section{CHAPTER 1: OVERVIEW \& GENERAL BACKGROUND}

Woodpeckers are widely considered to be forest-specialists with fairly large area requirements, yet they are regularly observed in fragmented and degraded forest patches such as urban parks. This thesis arises from two notable observations of Pileated Woodpeckers (Dryocopus pileatus) in highly urbanized environments. In the spring of 2014 I observed two Pileated Woodpeckers exhibiting courtship behavior at Smith and Bybee Wetlands, a natural area in north Portland containing 76 ha of cottonwood forest surrounded on all sides by extensive industrial development, open water and a multilane interstate highway. In undeveloped landscapes, breeding season home ranges of Pileated Woodpeckers in Pacific Northwest forests averaged 478 ha (Mellen et al. 1992), more than six times larger than the usable habitat area at Smith and Bybee. The nearest forest patch of this size was five kilometers away, and would have required birds to make a more or less continuous flight across a dense anthropogenic matrix. It was unclear whether these individuals were breeding at Smith and Bybee, or on a long foraging bout and were nesting elsewhere.

On another occasion I watched a Pileated Woodpecker foraging on the ground during rush hour on the shoulder of Macadam Avenue in southwest Portland. It did not appear to be bothered by two lanes of congested traffic, nearby construction or a stream of cyclists and runners. The bird then made a single, long flight to the east across the Willamette River and continued in the direction of the forested buttes in southeast Portland. 
Observations such as these suggested to me that woodpeckers might be more flexible in their habitat associations and area requirements than would be predicted by current research. They raised key questions regarding the ability of woodpeckers to adapt to an urban landscape. Can woodpeckers sustain themselves in substantially smaller forest patches than they would in larger remote forests? If so, what are their functional area requirements in fragmented urban landscapes? How tolerant are woodpeckers of human disturbance such as industrial development, automobiles, pedestrian traffic and dogs? What habitat and landscape characteristics benefit urban woodpecker populations, and what conditions hinder them? My master's research addresses some, but certainly not all, of these questions and will hopefully provide park managers with useful data for the management of urban parks and the conservation of woodpeckers.

Little is known about the ways that animals use urban forests in general, and almost no data exist on woodpeckers in urban environments. Historically, field studies and management strategies have focused their efforts on rural landscapes. In Oregon, prominent research on woodpeckers has occurred on large expanses of Forest Service land in remote regions of the state (see Mannan 1984, Mellen et al. 1992, Bull and Holthausen 1993). Although such studies provide valuable life history information, woodpeckers may exhibit different behaviors and habitat requirements in urban areas. Urban landscapes feature unique patterns of land-use, forest fragmentation, development, and human activity, presenting wildlife with novel challenges and opportunities. I have found only two published papers exploring habitat associations of woodpeckers in urban areas, signaling a major gap in scientific understanding. Morrison and Chapman (2005) 
assessed the influence of habitat variables on woodpecker presence in six parks in Hartford, CT. They reported that the number of trees, basal area, and park area explained over $90 \%$ of variation in woodpecker density among parks. Although these findings are relevant to my research, they examined only within-patch characteristics, providing no measure of anthropogenic or biogeographic influences. In a compelling study of woodpeckers in Poznan, Poland, Myczko et al. (2014) identified urbanization level and patch size as major drivers of woodpecker abundance. These two variables were present in their best model, along with canopy openness and percentage share of deciduous tree species. Canopy openness had a negative effect, and percentage of deciduous trees had a positive effect, on woodpecker abundance. Their findings suggest that (i) woodpeckers are an efficient indicator of the impact of urbanization on forested areas, and (ii) to improve habitat suitability for woodpeckers, urban parks should be large, multistoried, and contain deciduous trees.

Both studies represent very different forest and climate conditions than the conifer-dominated and riparian-hardwood forests found in the Pacific Northwest. Morrison and Chapman surveyed temperate deciduous forests dominated by maple (Acer spp.), oak (Quercus spp.), and ash (Fraxinus spp.). Myczko et al. surveyed Scots pine (Pinus sylvestris) stands with occasional oak and ash along riparian corridors. I sampled five species of woodpeckers, which differ substantially in their foraging habits and migratory patterns. Pileated, Hairy (Picoides villosus), and Downy (P. pubescens) woodpeckers represent the prototypic woodpecker, excavating holes in dead and dying wood to access invertebrate prey (Rodewald 2015). They are mostly non-migratory in the 
portion of their range where my research occurred (Marshall et al. 2006). Northern Flickers (Colaptes auratus) are primarily ground-foragers and are migratory in the more seasonal parts of their range, while Red-breasted Sapsuckers (Sphyrapicus ruber) belong to a genus of highly specialized sap-sucking species that are migratory (Rodewald 2015). These interspecific differences, and the overall lack of information on how woodpeckers utilize urban landscapes, suggest a need for formal research on urban woodpecker populations.

To the best of my knowledge, my research is the first to examine the effects of urbanization and urban forest conditions on woodpeckers in the western U.S. As trends toward urbanization continue to grow, this information will become increasingly critical. Currently, $81 \%$ of U.S. citizens reside in urban areas and this figure is predicted to rise (Growth in Urban. 2012). The greater Portland metropolitan area saw a population increase of 600,000 people since 2005 , and is expected to expand by another 725,000 people by 2035 (Mistreanu 2014). With this staggering increase comes a growing need to understand the ecological role of urban spaces for wildlife, and to strengthen conservation efforts within these spaces.

Urban forests may have direct benefits for human populations as well. Maas et al. (2009) found an inverse correlation between availability of urban greenery and diagnosed morbidity such as depression and anxiety. Taylor et al. (2015) corroborated these findings by demonstrating that areas of London with higher street tree density had lower antidepressant prescription rates. Thus, the conservation of urban forests will have measurable impacts on humans and wildlife in years to come. 
My research addresses two questions that have implications for the management of urban spaces for woodpecker populations: (i) What are the ecological, anthropogenic, and biogeographic determinants of woodpecker abundance, and (ii) what are the minimum area requirements of these species, and how can urban parks be managed to support them? Chapter 2 deals with the first question, and assesses the habitat associations of woodpeckers in urban parks. I surveyed woodpecker populations in 36 urban parks and examined correlations between their abundance and a complex of habitat variables (e.g. park area, tree and snag density, understory composition and characteristics of the surrounding landscape matrix). I found that most woodpecker species increased in abundance as a function of park area and understory vegetation. I recommend that the protection of large, multistory forest patches should be prioritized in urban areas.

Chapter 3 addresses the second question, and examines spatial requirements of woodpeckers in a fragmented urban landscape. Using predicted probabilities of occurrence based on woodpecker presence-absence data, I generated minimum area requirements for each of the five woodpecker species included in the study. Pileated and Hairy woodpeckers exhibited the most pronounced area-sensitivity, and I estimated their minimum area requirements in urban forests to be 51 and 34 ha, respectively. I suggest that local management decisions should be made based on these findings, and that conserving contiguous forest patches of approximately 50 ha or more will benefit all woodpecker species in urban landscapes. 


\begin{abstract}
Urbanization is a driving force in the loss of native habitat and biodiversity. In this context urban parks are essential to the maintenance of biodiversity by providing patches of remnant forest that may be particularly valuable to forest specialists such as woodpeckers (Picidae). Woodpeckers perform a critical ecosystem function by creating cavities that are used by a suite of other forest organisms, yet little information exists on urban woodpecker ecology. I investigated the habitat and landscape components associated with woodpecker abundance in 36 urban parks throughout Portland, Oregon, ranging in size from 0.9 to 1337 ha. Five species of woodpeckers were detected in the 2015-16 breeding season using point counts and audio broadcast surveys at multiple survey stations within each park. The relationships between woodpecker abundance and a suite of habitat variables were analyzed using generalized linear models. Woodpecker species demonstrated different habitat associations, but park area and understory structure were important variables in most final models. Abundance of the two largest species also responded either negatively (Northern Flicker [Colaptes auratus]) or positively (Pileated Woodpecker [Dryocopus pileatus]) to the presence of forest cover in the landscape surrounding parks. I recommend that park managers protect large, multistory forest patches. These environments appear to benefit woodpeckers, and in all probability, the many species associated with woodpecker occurrence.
\end{abstract}




\section{Introduction}

Over the last 200 years, urbanization has drastically transformed the natural landscape, presenting novel challenges and opportunities for wildlife. Urbanization has resulted in the alteration, fragmentation, and loss of naturally dynamic ecosystems, especially contiguous forested habitat (Morrison and Chapman 2005, Evans et al. 2009, Meffert and Dziock 2013). In this context, remnant forest patches such as urban parks may be a critical resource allowing many species to persist in urban areas, thus increasing or maintaining regional biodiversity (Evans et al. 2009, Ikin et al. 2013). Urban parks can function as islands of usable forest amidst a sea of urban development (Fernández-Juricic and Jokimäki 2001, Fernández-Juricic 2004, Platt and Lill 2006). There is a large body of research exploring the value of urban forest patches from an island biogeographic perspective. Perhaps most notable is Diamond's (1975) application of the island metaphor to other natural habitats, in which he proposed that ecological islands are increasingly critical for species' survival in man-made habitats, and that the number of species that an island can sustain is a function of patch size, shape, and connectivity. Consistent with these predictions, recent studies have demonstrated a positive correlation between park area, connectivity, and species richness (Platt and Lill 2006, Bräuniger et al. 2010, Fitzsimons et al. 2011). While urban matrix effects are consistently found to affect species richness negatively (Haddad et al. 2015), urban parks and greenspaces can represent hotspots of species richness within the landscape (Nielsen et al. 2014, Strohbach et al. 2013). 
Urban parks may be particularly important for forest specialists such as woodpeckers and the secondary cavity nesters that use old woodpecker nests (Mikusinski et al. 2001, Myczko et al. 2014). These species depend on prominent forest features such as large and old trees, snags, downed wood, and canopy closure, which are often sacrificed for urban development (Mikusinski and Angelstam 1998, Setterington et al. 2000). Urban parks have the potential to provide such features. LaMontagne et al. (2015) found that woodpecker cavities and snags were rare in developed neighborhoods, but had similar rates of occurrence in both urban parks and rural forests, suggesting that woodpeckers may rely on urban parks to provide the resources required for breeding in urban landscapes.

Woodpeckers are well suited for studying the effects of urbanization on forestdwelling species for a number of reasons. Because they rely on trees and are closely associated with forest conditions, many woodpeckers are sensitive to alterations of forested environments. Thus, changes in their population dynamics and reproductive success may reflect the quality of the forests they occupy (Angelstam 1990, Mikusinski et al. 2001, Drever et al. 2008). Woodpeckers have played an important role as indicator species guiding management decisions. The USDA Forest Service has designated Pileated Woodpeckers (Dryocopus pileatus) and Black-backed Woodpeckers (Picoides arcticus) as management indicator species for mature forests and burned forests, respectively (Duncan 2003, Saracco et al. 2011). In Portland, Oregon, city biologists designated the Pileated Woodpecker as a focal species for management and conservation in Forest Park, a 2100 ha forest reserve in Portland's west hills (Portland Parks \& 
Recreation 2011). Due to the ecological constraints imposed by urban landscapes, and the sensitivity of woodpeckers to their environment, woodpeckers offer a compelling framework for studying urban forest conditions.

Many woodpeckers are considered keystone species because they excavate tree cavities that are subsequently used by a suite of other organisms for food storage, breeding, and shelter (Martin and Eadie 1999, Russell et al. 2009, Cockle et al. 2011). In North America, more than 89 species use tree cavities, making them a vital component of forest biodiversity (Conner et al. 2001, Martin et al. 2004, LaMontagne et al. 2015). The availability of excavated cavities depends on populations of primary excavators such as woodpeckers. The occurrence of woodpeckers, therefore, facilitates and indicates the potential presence of numerous cavity-associated species (Shackelford and Conner 1997, Drever et al. 2008). Moreover, positive associations between woodpecker species richness and the species richness of other birds in native forests suggests that management for woodpeckers may simultaneously benefit other bird species (Drever and Martin 2010).

The foraging activities of woodpeckers have also led to their designation as ecosystem engineers and habitat modifiers. Woodpeckers excavate holes in dead, decaying, and live wood to access invertebrate prey. By doing so they accelerate decay processes and nutrient cycling, assist in the inoculation of heart-rot fungi, and can mediate insect outbreaks (Duncan 2003, Farris et al. 2004). These behaviors influence avian diversity by removing bark from trees, exposing the underlying substrate for foraging by other bird species (Bull and Jackson 1995). Mikusinski et al. (2001) and 
Roberge and Angelstam (2006) found that woodpecker species were among the best indicators of overall avian diversity in forest habitats. Consequently, determining habitat requirements of urban woodpeckers will improve the guild's potential to persist in urbanfragmented landscapes and, importantly, benefit a broad network of species.

Despite the recognized value of woodpeckers to forest ecosystems (Drever et al. 2008), little research exists on urban woodpecker populations (but see Morrison and Chapman 2005, Myczko et al. 2014). To the best of my knowledge this is the first study to examine the effects of urbanization and urban forest conditions on woodpeckers in the western U.S. My objectives were to (i) identify the habitat determinants of woodpecker abundance and (ii) provide specific management recommendations for urban parks. I used point counts and audio broadcasts to survey five woodpecker species (Downy Woodpecker [P. pubescens], Red-breasted Sapsucker [Sphyrapicus ruber], Hairy Woodpecker [P. villosus], Northern Flicker [Colaptes auratus], and Pileated Woodpecker) during the 2015 and 2016 breeding seasons in parks throughout Portland, Oregon. Portland is a city of 619,000 people that is expected to more than double in size in the next 20 years (Mistreanu 2014), and the development pressure on current forested areas will therefore only rise. I thus hypothesized that woodpecker occurrence and abundance would vary across different parks within the landscape, depending on a combination of ecological, geographic, and anthropogenic variables. Within-park habitat features such as downed logs, snags, and canopy cover are commonly understood to benefit woodpeckers and other forest species. Conversely, anthropogenic influences such as road density and development may pose unique challenges to urban wildlife. 
Therefore, I predicted that woodpecker abundance would generally increase with park area, snag density, canopy cover, and forest connectivity. I expected also that shrub density would have a negative correlation with woodpecker abundance because shrubs may block access to downed logs for insect foraging. Connectivity of fragmented parks is largely mediated by forest cover in the surrounding landscape. High tree cover facilitates movement of birds in urban spaces (Tremblay et al. 2009, 2011), and thus I further predicted that woodpecker abundance would be adversely affected by losses of tree cover and increased urban development surrounding parks and greenspaces.

\section{Methods}

Study area

I conducted this study in Portland, Oregon, USA ( $\left.45^{\circ} 31^{\prime} \mathrm{N}, 122^{\circ} 40^{\prime} \mathrm{W}\right)$, a city that covers $376 \mathrm{~km}^{2}$ and is surrounded by extensive urban and suburban development. The greater Portland metropolitan area encompasses $17,300 \mathrm{~km}^{2}$. Tree canopy covers $31 \%$ of the city in an equally distributed pattern, with many trees found in residential areas (Portland Parks \& Recreation 2017). A total of 279 parks and natural areas, comprising over 4,000 ha, are irregularly distributed throughout Portland's urban matrix. Dominant tree species include black cottonwood (Populus trichocarpa), Oregon ash (Fraxinus latifolia), pacific willow (Salix lucida), and red alder (Alnus rubra) in riparian areas, and big leaf maple (Acer macrophyllum), Douglas fir (Pseudotsuga menziesii), and western red cedar (Thuja plicata) in upland forests. Portland is particularly relevant for studying urban woodpecker biogeography because it is a large, rapidly growing city with a wide 
array of habitats and patch sizes. Therefore, it provides an excellent opportunity to investigate the way woodpeckers respond to a complex of ecological and anthropogenic pressures.

\section{Park selection}

For the purposes of this study, parks were defined as remnant forest fragments within the Portland metropolitan area, with $>50 \%$ canopy closure. Thirty-six parks were nonrandomly selected to characterize the range of available forest types and patch sizes found throughout the city (Figure 2.1). Twenty-six parks were initially chosen and surveyed in 2015. Ten more parks were added in 2016 to increase sample size and diversify the types of parks selected. I consulted with biologists at the City of Portland to ensure that a representative array of parks was chosen. Parks were delimited on the basis of canopy closure, roads, urban development, and open water using ArcGIS. Parks ranged in size from 0.9-1337 ha, and encompassed a variety of habitat types including broadleaf riparian woodlands and upland mixed-conifer forests.

Each park contained between 1 and 6 survey stations. The number of stations per park was proportional to park area on a logarithmic scale. Stations were established randomly in ArcGIS such that there was a minimum distance of $200 \mathrm{~m}$ between points and all were $\geq 100 \mathrm{~m}$ from the park boundary (Setterington et al. 2000). This minimized the likelihood of double counting birds or detecting birds outside of the park. 


\section{Woodpecker surveys}

Three surveys were conducted at each park between April and June, spaced at approximately one-month intervals. Twenty-six parks were surveyed in 2015, and 10 more were surveyed in 2016 . To test for temporal variation between survey years a random subset $(n=8)$ of the initial 26 parks was revisited in 2016. Paired t-tests were used to compare woodpecker abundance between years. There were no significant differences in abundance between survey years $(p<0.05)$ and therefore I analyzed all 36 parks together without consideration of year.

I surveyed woodpeckers at each station using variable circular-plot point counts and audio broadcast surveys (Kumar and Singh 2010). Point-based surveys were chosen over strip transects because it is easier to assess the role of habitat and landscape variables on bird occurrence at discrete points on the landscape (Reynolds et al. 1980; R. Siegel, pers. comm.). Audio broadcasts were used to increase detectability, since a previous study in Portland, OR found that woodpeckers were rarely detected during 10minute passive counts (Murphy et al., unpublished data). A 3-minute passive point count was conducted following the Breeding Bird Survey protocol (United States Geological Survey 1998), followed by a sequence of audio broadcasts. The call and drum of each species was broadcast twice-once facing due north and once due south-with a $30 \mathrm{~s}$ observation interval between broadcasts. The broadcast sequence was conducted in order of species' body size from small-to-large (Quayle and Westereng 1999) and the speaker volume was set to avoid overlap between survey stations. All woodpeckers seen or heard were identified by species, sex, and age and distance to each individual was measured 
using a rangefinder in accordance with standard distance sampling methodology (Buckland et al. 2001). Woodpecker detections at all survey stations were summed for each park. Any suspected case of double counting was treated as a single record, and I am confident that all records used in my analyses were independent. All woodpecker surveys occurred between sunrise and 1000 on days without heavy rain or wind.

\section{Predictor variables}

Twelve variables were considered as possible predictors of woodpecker abundance (Table 2.1). Habitat variables were measured at all woodpecker survey stations to describe forest structure and a landscape analysis was performed for each park using ArcGIS. Park area was calculated as the total forested area within each park. I characterized stand composition and vegetation structure in $11.3 \mathrm{~m}$ radius plots following James and Shugart (1970). Snags (standing trees $>50 \%$ dead) were measured separately from live trees using the same protocol. Trees and snags $\geq 8 \mathrm{~cm}$ diameter at breast height (DBH) were counted, measured, and identified to species. The relative importance value of deciduous trees was defined as the proportion of total basal area contributed by deciduous species (i.e., deciduous basal area $\div$ total basal area). It is inversely proportional to the importance value of coniferous species, and therefore a low percentage of deciduous trees would indicate a high percentage of coniferous trees. All vegetation measurements were averaged for the whole park and scaled to one hectare to facilitate comparison between parks. The forest cover, road density, and building cover within a $500 \mathrm{~m}$ buffer around each park was calculated in ArcGIS using spatial data from 
the Portland Bureau of Planning and Sustainability. I included a binary categorical variable to distinguish between traditional parks lacking an understory but with abundant grass cover, and natural areas with an understory dominated by native shrubs and herbaceous plants. Parks without understory features had mature trees and canopy closure but were generally managed for human recreation.

\section{Statistical Analyses}

I defined woodpecker abundance for each species as the total number of individuals detected within each park (MacNally 2007, Stralberg et al. 2010). By adding the number of sampling events as an offset variable in later analyses, this metric functioned as an abundance index, providing a woodpecker count that was scaled to park size based on the number of surveys made in each park. This provides an accurate assessment of intraseason abundance when multiple visits are made to a survey site (Betts et al. 2005). It presumably reflects reproductive activity at a park because individuals observed repeatedly throughout a breeding season are likely to be active breeders. Although I did record observations of breeding and pair behavior, I did not translate individual counts into numbers of pairs. I assumed that using the actual number of individuals detected would provide a more accurate measure of woodpecker abundance than would extrapolation based on breeding behavior. Further, I did not use detection probabilities to adjust woodpecker counts because audio-broadcasts attract birds and skew distance estimations. Woodpeckers seen or heard but not identified to species were not included in analysis ( $n=9,<1 \%$ of all detections). 
Statistical analysis was accomplished in two stages using programs R and JMP: (i) an exploration of multicollinearity and data distribution of all variables and (ii) an analysis of woodpecker habitat associations using generalized linear models with Poisson distribution and log-link function for each species. The number of surveys was included as an offset (log-transformed) to account for differences in sampling effort among parks. To minimize variable redundancy prior to model selection, correlations between predictor variables were assessed using Pearson product-moment correlations and variable inflation factors (VIF). An inclusion cutoff of $r=0.70$ was set, above which one of the two correlated variables was eliminated, or the variables were combined through principal component analysis. Tree and snag density were highly correlated $(r=0.80)$. Snag density was retained due to the importance of snags to woodpeckers. Road density and building cover were also highly correlated $(r=0.86)$. The first principal component between these two variables accounted for $96 \%$ of the variation in each variable and was used as a single urbanization index in later analyses. Park area varied over three orders of magnitude and therefore it was $\log _{10}$-transformed. I also added the quadratic term of logtransformed park area to account for potential nonlinearity in the relationship between woodpecker abundance and area (Schielzeth 2010).

I used generalized linear models to determine which variables best predicted variation in woodpecker abundance. An information-theoretic approach was used for model selection (Burnham and Anderson 2002, Ellis et al. 2014). Criterion-based model selection is fitting for studies of complex environmental systems and data spanning a large spatio-temporal scale, as it measures the relative quality of all models based on 
Akaike's Information Criterion (AIC). A full model was constructed for each species including the 11 final predictor variables (Table 2.1). All predictor variables, with the exception of the categorical variable describing understory, were standardized ( $Z$-scores) prior to analysis to facilitate comparisons of their relative influence on woodpecker abundance (Schielzeth 2010, LaMontagne et al. 2015). Variables were evaluated using a criterion-based backward stepwise procedure, successively removing variables until the strongest model (i.e., minimal adequate model) was produced. Models were ranked according to their $\triangle \mathrm{AIC}$ values. All models with $\triangle \mathrm{AIC}<2$ were considered equally good and are reported below (Burnham and Anderson 2002), however I provide interpretation of only the top model $(\Delta \mathrm{AIC}=0)$. A pseudo- $R^{2}$ for each model was calculated by dividing the difference in deviance between the null model and the top model by the null model's deviance (Y. Pan, pers. comm.).

Diagnostic checks were performed on the final models to ensure model adequacy and goodness of fit. Potential outliers were examined using Cook's distance and VIFs were generated to check for issues of multicollinearity. Lastly, an analysis of variance (ANOVA) was performed to determine whether the final models were significantly different from the full model.

\section{Results}

\section{Woodpecker distribution and abundance}

A total of 1321 woodpecker observations were made during the surveys. After accounting for individuals detected at multiple stations and averaging for three survey 
visits, the estimated total woodpecker count (i.e. number of individuals detected) was 344 throughout the study area. Woodpecker abundance varied across parks, ranging from 0 to 24 individuals, with an average of 10 individuals detected per park. Northern Flickers and Downy Woodpeckers were the most and second most abundant species, respectively, together comprising $65 \%$ of all detections (Table 2.2 ). Both were present at nearly every park and seemed to be well distributed across the forested landscape. Red-breasted Sapsuckers were found at most parks and exhibited moderate abundance in comparison to the other species. Pileated Woodpeckers were the least abundant species and were observed at only 19 parks. Hairy Woodpeckers showed remarkably similar distribution to Pileated Woodpeckers and were present at only four parks where the other was absent.

\section{Characterizing predictor variables}

Predictor variables varied widely across the 36 parks (Table 2.3), especially park area, forest cover surrounding parks, snag density and the density of downed logs. Parks ranged over three orders of magnitude in size (Table 2.3). Although the average park area was nearly 100 ha, median park area was roughly a quarter of that size (Table 2.3). Many of the variables describing understory structure, such as downed logs, shrub count and snag density were entirely absent from parks managed for human recreation. These sites, which I refer to as "pantless parks," had large trees and canopy closure above but were cleared beneath. Canopy cover showed the lowest variability among parks (Table 2.3; CV $=14.0 \%$ ), and averaged $77 \%$, which is unsurprising because parks were in part chosen 
based on forest closure. The forested area within a $500 \mathrm{~m}$ buffer of each park ranged from $1.4-63 \%$.

\section{Woodpecker abundance models}

Final models analyzing the relationship between woodpecker abundance and the suite of predictor variables (from Table 2.1) are presented for each species in Table 2.4. The standardized regression coefficients associated with each predictor variable are provided in Table 2.5. The descriptions that follow are based on the top model $(\Delta \mathrm{AIC}=0)$ for each species. Park area was the only predictor variable present in top regression models for all five woodpeckers species. Four of five species exhibited a second-order polynomial relationship with park area indicating that abundance increased as a function of park area but then reached an asymptote at larger park sizes (Table 2.5). The only exception was the Hairy Woodpecker, which showed a simple linear rise in abundance as park area increased. The presence of understory vegetation was also a prominent variable associated with an increase in abundance for four species, with the only exception being Pileated Woodpeckers. Although the regression coefficient produced by understory vegetation was not directly comparable to other variables because it was not standardized (Schielzeth 2010), the presence of this variable in four of five species indicates its overall importance. The percentage share of deciduous trees was correlated with an increase in Downy and Pileated woodpecker abundance, but negatively influenced Northern Flickers. Canopy closure was associated with an increase in Hairy Woodpecker and Northern Flicker abundance, while increasing urbanization in the landscape surrounding 
parks negatively influenced Red-breasted Sapsuckers and Northern Flickers. High forest cover in the surrounding landscape affected Northern Flicker abundance negatively and Pileated Woodpeckers abundance positively. Two remaining variables had associations with single species; Downy Woodpecker abundance was greater in parks with high tree basal area while Pileated Woodpeckers exhibited greater abundance in parks with high shrub counts. Notably, Pileated Woodpeckers were the only species that did not exhibit an association with the categorical variable describing understory, possibly because the effect was better described by shrub count.

\section{Discussion}

Habitat associations varied among the five woodpecker species included in my study, however there were several commonalities that provide important insights for managing forests in urban landscapes. Most notably, park area was a major predictor of woodpecker abundance for all five species. While it may seem obvious that larger habitat parcels should hold more individuals, I corrected for an increase in number of surveys with park size by adding an offset variable (number of survey stations per park) in the regression modeling, so my measure of woodpecker abundance can be interpreted as a rough estimate of woodpecker density. Not only did large urban parks hold more individuals, they also seemed to support more woodpeckers per unit area. Interestingly, the quadratic term of park area indicated that 4 of 5 species either reached an asymptotic abundance as park area increased (Red-breasted Sapsuckers and Pileated Woodpeckers) or possibly even declined (Downy Woodpeckers and Northern Flickers; see Chapter 3) in the very 
largest forest patches. The two largest parks I sampled were the northern and southern portions of a $\sim 2100$ ha natural area called Forest Park. When combined, they are more than 8 times larger than the next biggest park I surveyed. Accordingly, woodpecker abundance seemed to increase with area until all but the very largest urban parks were sampled. Hence, parks $>600$ ha may not be more beneficial to woodpecker abundance than a 300 ha park of comparable habitat quality. Nonetheless, given the constraints imposed by urban environments, the size of contiguous forest patches is likely the single most important variable affecting woodpeckers in urban environments. I recommend that the establishment and conservation of mid to large-sized parks ( $\sim 30-300 \mathrm{ha})$ be prioritized for the benefit of woodpeckers and other cavity-dependent species.

Internal habitat variables also influenced woodpecker abundance. The presence of understory vegetation, which I used to distinguish between traditional and nontraditional parks, was positively correlated with abundance for every species except Pileated Woodpeckers. However, the top model describing Pileated Woodpecker abundance contained shrub count as a positive predictor, which describes a similar habitat characteristic. The presence of multistory vegetation in urban parks, including shrubs, snags, and understory trees, was an important predictor of woodpecker abundance. Canopy closure also had a positive effect on the abundance of Hairy Woodpeckers and Northern Flickers. However, canopy cover by itself is undoubtedly not a sufficient condition for maintenance of woodpecker abundance because, as noted above, 7 of the 36 parks had closed canopies but lacked understory vegetation, and woodpeckers were less abundant in these environments than in parks with multistory vegetative structure. Parks 
managed primarily for human recreation, even though they all had tall trees and good canopy closure, did not produce habitat suitable for sustaining woodpeckers and no doubt other forest wildlife. The presence of understory complexity is likely to be a meaningful variable.

Two other habitat variables had mixed effects that likely reflected the foraging ecology of individual species. The importance value of deciduous trees was positively associated with Downy and Pileated woodpecker abundance, but Northern Flickers declined as the representation of deciduous trees in the park increased. High importance of deciduous trees was characteristic of mixed deciduous-coniferous forests in my sample and these possibly provided a greater diversity of foraging substrates for most barkforaging woodpeckers. The reason for the general decline of Northern Flickers in forests with a heavy deciduous tree importance is not entirely clear, but flickers differ from other woodpeckers because they forage extensively on the ground (Rodewald 2015). Forests with a stronger coniferous component may produce less ground cover that could interfere with their foraging. The response of Pileated Woodpeckers (increase) and Northern Flickers (decrease) to forest cover in the surrounding landscape also differed. High forest cover in the landscape surrounding parks translates into greater connectivity (Tremblay et al. 2009, 2011), which for a forest-dependent species with large area requirements (i.e. Pileated Woodpeckers) may be an essential feature to facilitate movement among suitable forest fragments. Because high levels of forest connectivity increase the effective size of urban parks by expanding the useable forested area, Pileated Woodpeckers, more than any other species, would benefit from residing within a landscape with high forest cover. 
By contrast, Northern Flickers depend heavily on open spaces such as lawns, golf courses, and playing fields for foraging and thus reduced and patchy forest cover likely represents an increase in usable foraging space.

Interestingly, my measurement of snag density was not present in any of the final regression models except for pileated woodpeckers (Table 2.4). It was present in the second strongest model and had a weak negative correlation with pileated woodpecker abundance. I hypothesized that snag availability would be important to woodpeckers because they require standing dead wood for foraging and nesting. Because I sampled vegetation characteristics at 1-6 $11.3 \mathrm{~m}$ radius plots per park, it is possible that snags were underrepresented in my dataset. Snags may have been present in nearby sections of the park, or in adjacent forest patches that were not sampled. Clearly, my data do not lead to the conclusion that snags were unimportant for urban woodpeckers. Rather, I suggest that either the methods I used or the specific habitats that I sampled may not have adequately captured snag availability. Snags are often removed as safety concerns in urban forests and I would argue that my results not be used to support such efforts because the relationship between snag availability and woodpecker abundance needs further study.

\section{Conclusions}

Woodpeckers are widely regarded as forest-specialists, requiring habitat components not often associated with urban landscapes (Styring and Ickes 2001). However, despite conducting my research in a rapidly urbanizing city with extensive human development, 
all five of the woodpecker species that occur in northwestern Oregon were found regularly in parks of varying sizes. This suggests that urban parks have the potential to support forest-specialists and even urban-avoider species. Forested parks are no doubt a critical resource sustaining local populations of these species, and usable forest patches are often scarce and small in urban settings.

My data indicate strongly that the size of forest fragments is a critical factor influencing woodpecker abundance. Indeed, patch size has been consistently shown to have a profound influence on species richness, abundance, and reproductive success in both urban and rural landscapes (Gavareski 1976, Fernández-Juricic 2004, Myczko et al. 2014). My findings support this general conclusion and indicate that park area is the most important driver of woodpecker abundance in fragmented urban landscapes. Patch size is particularly important to area-sensitive species such as Pileated and Hairy Woodpeckers, whose foraging, breeding, and dispersal activities may be limited by urban matrix effects.

Understory complexity was a second major factor influencing the woodpecker assemblage, second only to park area. Interior forest conditions have been identified as drivers of bird abundance (Evans et al. 2009), though it is likely that they are less important than habitat patch size overall (Kang et al. 2015). Urban woodpeckers benefit from large structurally complex forest patches. Protecting these environments is critical for the conservation of woodpeckers and other forest-associated species.

More than half of the world's human population, and $81 \%$ of U.S. citizens, currently reside in urban areas, and these numbers are predicted to rise ("Growth in Urban.” 2012). With this increase comes a growing need to understand the ecological 
role of urban spaces, and to strengthen conservation efforts within these spaces. The maintenance of regional biodiversity in urban areas will depend largely on the quality and availability of forested parks (Marzluff and Ewing 2001). Based on my findings, I suggest that forest patch size is the most critical variable affecting woodpeckers in urban landscapes. Urban planners and park managers should prioritize the establishment and protection of larger forested parks ( 30-300 ha), with an emphasis on maintaining naturally dynamic understory and canopy closure. Doing so will benefit woodpeckers and have positive cascading effects on the diverse network of species associated with woodpecker occurrence (see also Drever and Martin 2010). 
Table 2.1: Predictor variables potentially influencing woodpecker abundance in urban parks located in Portland, Oregon, and surveyed between April and June 2015 and 2016.

\begin{tabular}{|c|c|c|}
\hline Variable & Description & Predicted $\beta$ \\
\hline AREA & Park area (ha) & + \\
\hline TDENS & Trunk count of trees $\geq 8 \mathrm{~cm} \mathrm{DBH}$ & + \\
\hline BASAL & Total basal area of trees $\geq 8 \mathrm{~cm} \mathrm{DBH}\left(\mathrm{m}^{2}\right)$ & + \\
\hline DECID & Relative importance value of deciduous trees $(\%)$ & $\sim$ \\
\hline SDENS & Trunk count of snags $\geq 8 \mathrm{~cm} \mathrm{DBH}$ & + \\
\hline LOGS & Total length of downed $\log _{\mathrm{S}} \geq 8 \mathrm{~cm} \mathrm{DBH}(\mathrm{m})$ & + \\
\hline SHRUBS & Stem count of shrubs & - \\
\hline UNDERSTORY & Categorical variable describing presence of understory $(0 / 1)$ & + \\
\hline CANOPY & Canopy cover within each park (\%) & + \\
\hline FOREST & Percentage of forested area within $500 \mathrm{~m}$ buffer (\%) & + \\
\hline BUILDINGS & Building cover within $500 \mathrm{~m}$ buffer $\left(\mathrm{m}^{2}\right)$ & - \\
\hline ROADS & Linear length of roadways within $500 \mathrm{~m}$ buffer $(\mathrm{m})$ & - \\
\hline URBAN & First principal component between BUILDINGS \& ROADS & - \\
\hline
\end{tabular}

Variables in bold were retained in final model building. AREA was log-transformed before analysis (LogAREA), and I also included the quadratic term (LogAREA ${ }^{2}$ ). BUILDINGS and ROADS were combined into single urbanization index (URBAN) using principal component analysis. Predicted $\beta$ provides the hypothesized association of each variable with woodpecker abundance ("+" and "-" indicate woodpecker abundance should increase or decrease, respectively, with this variable. " $\sim$ " indicates the variable's effect may differ between species). 
Table 2.2: Detections and occupancy of five woodpecker species surveyed between April and June 2015 and 2016 in parks in Portland, Oregon.

\begin{tabular}{|c|c|c|c|c|}
\hline Species & Total count $(\%)^{\mathrm{a}}$ & $\begin{array}{l}\text { Average count per } \\
\text { survey } \pm \mathrm{SD}\end{array}$ & $\begin{array}{c}\text { Average count per } \\
\text { park } \pm \mathrm{SD}\end{array}$ & $\begin{array}{c}\text { Number of occupied parks } \\
(\%)^{\mathrm{b}}\end{array}$ \\
\hline Downy Woodpecker & $84(25 \%)$ & $0.52 \pm 0.33$ & $2.34 \pm 1.83$ & $34(94 \%)$ \\
\hline Red-breasted Sapsucker & $70(20 \%)$ & $0.39 \pm 0.29$ & $1.94 \pm 1.77$ & $32(89 \%)$ \\
\hline Hairy Woodpecker & $34(10 \%)$ & $0.18 \pm 0.20$ & $0.94 \pm 1.11$ & $23(64 \%)$ \\
\hline Northern Flicker & $138(40 \%)$ & $0.85 \pm 0.37$ & $3.84 \pm 2.42$ & $36(100 \%)$ \\
\hline Pileated Woodpecker & $18(5 \%)$ & $0.09 \pm 0.11$ & $0.50 \pm 0.63$ & $19(53 \%)$ \\
\hline
\end{tabular}

Total count is the estimated number of individuals detected across the entire study area, after correcting for multiple visits and repeated observations. Average count per survey is an abundance index- the mean number of individuals detected at any given survey station. Average count per park is the mean number of individuals detected at any given park. Number of occupied parks is the number of parks where each species was observed.

${ }^{a}$ Percentage of woodpeckers accounted for by each species.

${ }^{b}$ Percentage of 36 parks where each species occurred. 
Table 2.3: Summary statistics of predictor variables ${ }^{\mathrm{a}}$ used in the analysis of variation in woodpecker abundance among 36 parks in Portland, Oregon, surveyed between April and June 2015 and 2016. All variables were averaged for each park and scaled to 1 ha.

\begin{tabular}{|c|c|c|c|c|c|}
\hline Variable & Minimum & Maximum & Mean & Median & $\begin{array}{c}\text { Coefficient of } \\
\text { variation }\end{array}$ \\
\hline AREA & 0.87 & 1337.27 & 95.58 & 23.94 & 250.67 \\
\hline TDENS & 74.13 & 774.18 & 335.05 & 316.12 & 50.88 \\
\hline BASAL & 165.56 & 1099.42 & 545.87 & 535.03 & 36.03 \\
\hline DECID & 0.00 & 100.00 & 58.91 & 56.00 & 64.01 \\
\hline SDENS & 0.00 & 247.08 & 68.58 & 63.02 & 82.86 \\
\hline LOGS & 0.00 & 2644.54 & 917.09 & 885.65 & 78.49 \\
\hline SHRUBS & 0.00 & 120669.60 & 53198.50 & 52303.89 & 63.54 \\
\hline UNDERSTORY & 0.00 & 1.00 & NA & NA & NA \\
\hline CANOPY & 52.50 & 97.50 & 76.54 & 75.50 & 14.02 \\
\hline FOREST & 1.40 & 62.59 & 17.83 & 9.69 & 96.25 \\
\hline BUILDINGS & 87.34 & 2349.33 & 1101.63 & 1235.11 & 55.51 \\
\hline ROADS & 7.23 & 194.21 & 96.60 & 100.99 & 52.60 \\
\hline
\end{tabular}

${ }^{\text {a }}$ See Table 2.1 for a full description of predictor variables. UNDERSTORY was a categorical (binary) variable describing understory vegetation. Seven of 36 parks had canopy closure but no understory vegetation. 
Table 2.4: Best generalized linear regression models describing woodpecker abundance in urban parks throughout Portland, Oregon, surveyed between April and June 2015 and 2016. Variables ${ }^{\mathrm{a}}$ were selected by a criterion-based (AIC) backward stepwise approach. All models with $\triangle A I C \geq 2$ are presented. "+" or "-" indicate that the coefficient had a positive or negative correlation with woodpecker abundance.

\begin{tabular}{|c|c|c|c|}
\hline Model & AIC & $\triangle \mathrm{AIC}$ & Pseudo- $R^{2}$ \\
\hline \multicolumn{4}{|l|}{ Downy Woodpecker } \\
\hline LogAREA - LogAREA ${ }^{2}+$ UNDERSTORY + DECID + BASAL & 163.32 & 0.00 & 0.76 \\
\hline LogAREA - LogAREA $^{2}+$ UNDERSTORY + DECID + BASAL + LOGS & 164.87 & 1.54 & 0.77 \\
\hline \multicolumn{4}{|l|}{ Red-breasted Sapsucker } \\
\hline LogAREA - LogAREA ${ }^{2}+$ UNDERSTORY - LOGS - URBAN & 181.69 & 0.00 & 0.55 \\
\hline LogAREA - LogAREA ${ }^{2}+$ UNDERSTORY - URBAN & 181.83 & 0.14 & 0.53 \\
\hline \multicolumn{4}{|l|}{ Hairy Woodpecker } \\
\hline LogAREA + UNDERSTORY + CANOPY + LOGS & 149.61 & 0.00 & 0.44 \\
\hline LogAREA - LogAREA ${ }^{2}+$ UNDERSTORY + CANOPY + LOGS & 149.85 & 0.24 & 0.47 \\
\hline LogAREA - LogAREA ${ }^{2}+$ UNDERSTORY + CANOPY + LOGS - URBAN & 150.93 & 1.32 & 0.48 \\
\hline \multicolumn{4}{|l|}{ Northern Flicker } \\
\hline LogAREA - LogAREA ${ }^{2}+$ UNDERSTORY - DECID + CANOPY - FOREST - URBAN & 206.67 & 0.00 & 0.64 \\
\hline LogAREA - LogAREA ${ }^{2}+$ UNDERSTORY - DECID - FOREST - URBAN & 206.86 & 0.19 & 0.60 \\
\hline LogAREA - LogAREA ${ }^{2}+$ UNDERSTORY - DECID - FOREST & 207.39 & 0.72 & 0.57 \\
\hline \multicolumn{4}{|l|}{ Pileated Woodpecker } \\
\hline LogAREA - LogAREA ${ }^{2}+$ DECID + SHRUBS + FOREST & 95.44 & 0.00 & 0.63 \\
\hline LogAREA - LogAREA ${ }^{2}+$ DECID + SHRUBS + FOREST - SNAGS & 95.69 & 0.25 & 0.66 \\
\hline
\end{tabular}

${ }^{a}$ See Table 2.1 for a full description of predictor variables. 
Table 2.5: Coefficients $\pm S E$ and (p-values) from Poisson regressions describing the relationship between woodpecker abundance and a suite of biogeographic, landscape, and habitat variables ${ }^{\mathrm{a}}$ in 36 parks and greenspaces in Portland, Oregon during the 2015 and 2016 breeding seasons. All variables except UNDERSTORY (a categorical variable describing absence [0] or presence [1] of understory vegetation) were standardized (mean $=0$, standard deviation $=1.0)$ prior to analysis. Results of top models $($ AIC $=$ 0.000) are reported from backward stepwise regressions with number of sampling events per park included as an offset.

\begin{tabular}{|c|c|c|c|c|c|}
\hline Variable & $\bar{~}_{\text {DOWO }^{\mathrm{b}}}$ & RBSA $^{\mathrm{b}}$ & HAWO $^{\mathrm{b}}$ & NOFL $^{b}$ & PIWO $^{\mathrm{b}}$ \\
\hline LogAREA & $\begin{array}{c}0.303 \pm 0.114 \\
(0.006)\end{array}$ & $\begin{array}{c}0.408 \pm 0.142 \\
(0.002)\end{array}$ & $\begin{array}{c}0.434 \pm 0.112 \\
(<0.001)\end{array}$ & $\begin{array}{c}0.204 \pm 0.098 \\
(0.034)\end{array}$ & $\begin{array}{c}1.420 \pm 0.366 \\
(<0.001)\end{array}$ \\
\hline LogAREA $^{2}$ & $\begin{array}{c}-0.261 \pm 0.081 \\
(<0.001)\end{array}$ & $\begin{array}{c}-0.139 \pm 0.078 \\
(0.064)\end{array}$ & & $\begin{array}{c}-0.243 \pm 0.069 \\
(<0.001)\end{array}$ & $\begin{array}{c}-0.586 \pm 0.195 \\
(<0.001)\end{array}$ \\
\hline UNDERSTORY & $\begin{array}{c}0.816 \pm 0.042 \\
(0.037)\end{array}$ & $\begin{array}{c}1.820 \pm 0.617 \\
(<0.001)\end{array}$ & $\begin{array}{c}1.935 \pm 1.032 \\
(0.012)\end{array}$ & $\begin{array}{c}0.781 \pm 0.241 \\
\quad(<0.001)\end{array}$ & \\
\hline DECID & $\begin{array}{c}0.494 \pm 0.084 \\
(<0.001)\end{array}$ & & & $\begin{array}{c}-0.236 \pm 0.094 \\
(0.012)\end{array}$ & $\begin{array}{c}0.586 \pm 0.247 \\
(0.009)\end{array}$ \\
\hline CANOPY & & & $\begin{array}{c}0.359 \pm 0.106 \\
(<0.001)\end{array}$ & $\begin{array}{c}0.107 \pm 0.057 \\
(0.060)\end{array}$ & \\
\hline URBAN & & $\begin{array}{c}-0.273 \pm 0.085 \\
(0.001)\end{array}$ & & $\begin{array}{c}-0.183 \pm 0.085 \\
(0.031)\end{array}$ & \\
\hline LOGS & & $\begin{array}{c}-0.157 \pm 0.092 \\
(0.081)\end{array}$ & $\begin{array}{c}0.248 \pm 0.118 \\
(0.038)\end{array}$ & & \\
\hline FOREST & & & & $\begin{array}{c}-0.229 \pm 0.066 \\
(<0.001)\end{array}$ & $\begin{array}{c}0.394 \pm 0.203 \\
(0.050)\end{array}$ \\
\hline SHRUBS & & & & & $\begin{array}{c}0.684 \pm 0.203 \\
\quad(<0.001)\end{array}$ \\
\hline BASAL & $\begin{array}{c}0.141 \pm 0.067 \\
(0.037)\end{array}$ & & & & \\
\hline
\end{tabular}

${ }^{\mathrm{a}}$ See Table 2.1 for a full description of predictor variables.

${ }^{\mathrm{b}}$ DOWO = Downy Woodpecker; RBSA = Red-breasted Sapsucker; HAWO = Hairy Woodpecker; NOFL = Northern Flicker; PIWO = Pileated Woodpecker 


\section{Figure Legends}

Figure 2.1. Map of the study area in Portland, Oregon, showing the location of the 36 parks (black polygons) surveyed for woodpeckers in 2015 and 2016. The inset (lower right) indicates the location of the Portland metropolitan area within Oregon 


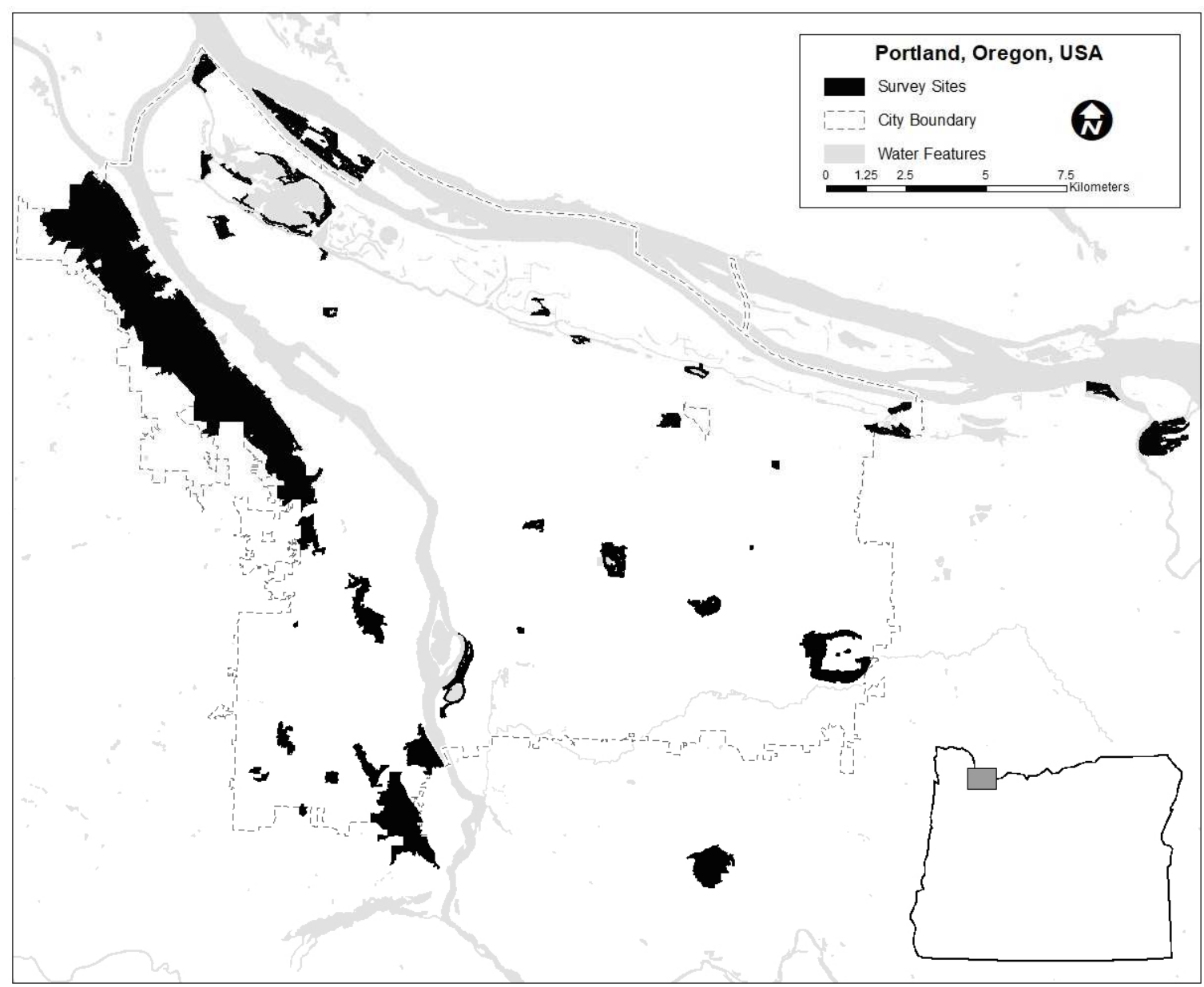

Figure 2.1 


\title{
CHAPTER 3: MINIMUM AREA REQUIREMENTS OF WOODPECKERS IN AN
}

\section{URBAN LANDSCAPE}

\begin{abstract}
The conservation of any species requires an understanding of its ecological and spatial requirements. These data are particularly critical in urban environments where space is a limited resource and habitats are often degraded. Woodpeckers contribute substantially to community dynamics of intact forest communities, but despite being prevalent in fragmented urban landscapes, no data exist on the spatial needs of woodpeckers in these spaces. Woodpeckers are ecosystem engineers, habitat modifiers, and keystone species. Therefore, determining their minimum area requirements could benefit a wide array of cavity-dependent species. I measured woodpecker occurrence in 36 forest patches throughout Portland, Oregon, and estimated minimum area requirements for each species using logistic regression probabilities. Pileated (Dryocopus pileatus) and Hairy (Picoides villosus) woodpeckers exhibited the most pronounced area-sensitivity, with minimum area requirements of 51 and 34 ha, respectively. Although other species exhibited less stringent area requirements, the probability of occurrence of all species increased with the size of park area. In managing urban forest fragments, priority should be given to meeting the needs of area-sensitive species such as Pileated and Hairy woodpeckers because doing so may help ensure the continued presence of the entire woodpecker guild across the landscape and promote regional biodiversity and forest health.
\end{abstract}




\section{Introduction}

Perhaps the greatest threat to global biodiversity is the loss and fragmentation of natural habitats (Kruess and Tscharntke 1994, Pereira et al. 2010, Fahrig 2013, Haddad et al. 2015). Urbanization is a major contributor to this habitat attrition (Nielsen et al. 2014), as urban development necessarily entails a reduction of natural areas. Urbanization has the potential to dramatically affect biodiversity because urban centers were often established at biotically rich locations such as the confluence of rivers or at estuarine coastal sites. The conversion of habitat for urban sprawl, highway systems, water reservoirs, and industrial infrastructure leaves a sparse mosaic of natural habitat, separated by a matrix of human land use (Robbins 1979, Haddad et al. 2015). The immediate effects of such fragmentation on wildlife habitat include the loss of area, increase in habitat isolation, and greater exposure to human activities through an increase in habitat edge (i.e. edge effect) (Andrén 1994, Lindenmayer and Fischer 2006). This has led to population declines in many species, particularly larger species with large spatial needs (Robbins 1979, Keinath et al. 2017). Area-sensitive species-those that require large, contiguous habitat patches and that are susceptible to population decline if their habitat is reducedmay be particularly restricted by urban landscapes, where space is a limited resource. Therefore, determining minimum area requirements (hereafter MAR) for such species is increasingly important as rates of urbanization climb. Conservation of these species should focus on providing the area of habitat necessary to sustain a local population. This study aims to quantify MAR for five woodpecker species in Portland, Oregon, a city of 619,000 people, which is rapidly expanding (Mistreanu 2014). Although patch area has 
consistently been found to be a driver of woodpecker abundance and species richness (Morrison and Chapman 2005, Myczko et al. 2014, Chapter 2), no data exist on their area requirements in fragmented urban landscapes. Given the anticipated rapid growth of cities in the near future, this information is critical to the persistence of woodpecker populations in urban environments.

Woodpeckers are compelling organisms to study and conserve for a number of reasons. First, woodpeckers are keystone species and ecosystem engineers because they are primary cavity excavators that provide resources (i.e. cavities) in living and dead trees that are subsequently used by a suite of other organisms for food storage, breeding, and shelter (Martin and Eadie 1999, Russell et al. 2009, Lorenz et al. 2015). The availability of cavities depends largely on populations of primary excavators like woodpeckers. In North America more than 89 species use tree cavities, making cavities a vital structural component of forest ecosystems (Conner et al. 2001, Martin et al. 2004, LaMontagne et al. 2015). Loss of woodpeckers would thus have gravely detrimental effects on numerous cavity-associated species (Shackelford and Conner 1997, Drever et al. 2008). Moreover, through their excavating activities woodpeckers accelerate decay processes and nutrient cycling, assist in the inoculation of heart-rot fungi, mediate insect outbreaks (Duncan 2003, Farris et al. 2004), and, by removing tough bark from trees, expose the underlying substrate to other bird species for foraging (Bull and Jackson 1995).

Second, woodpeckers are commonly considered habitat specialists (Ahlén 1975, Wesolowski and Tomialojc 1986). They use prominent forest features like large snags for nesting, and decadent live trees and downed logs for foraging (Raphael and White 1984, 
Mellen et al. 1992, Setterington et al. 2000). Because woodpeckers are closely associated with large forests and internal forest conditions, they are particularly sensitive to alterations or reductions of these environments (Syring and Ickes 2001, Lorenz et al. 2015). Special consideration may be required for conserving woodpeckers in fragmented or deforested landscapes.

Third, because woodpeckers are functionally linked to a variety of forest dwelling species, and because they are sensitive habitat specialists, changes in their populations reflect the overall quality of the forests they occupy (Drever et al. 2008). Mikusinski et al. (2001) and Roberge and Angelstam (2006) found that woodpecker species were among the best indicators of overall avian diversity in forest habitats. Accordingly, woodpeckers have played an important role as indicator species guiding management decisions. The USDA Forest Service has designated Pileated Woodpeckers (Dryocopus pileatus) and Black-backed Woodpeckers (Picoides arcticus) as management indicator species for mature forests and burned forests, respectively (Duncan 2003, Saracco et al. 2011). In Portland, Oregon, city biologists designated the Pileated Woodpecker as a conservation focal species in Forest Park, a 2100 ha forest reserve in Portland's west hills (Portland Parks \& Recreation 2011). Despite their designation as indicator species, no studies to date have generated minimum area requirements for woodpeckers in urban landscapes. Determining their area requirements will allow us to better manage urban forests to benefit woodpeckers and other forest-dwelling species.

A species' spatial requirements can be measured a variety of ways, with many overlapping and conflicting definitions. Territory size and home range may represent the 
most accurate and informative metrics. Territory size is the defended area occupied exclusively by an individual or group (Beer et al. 1956, Wilson 1975). Breeding birds generally defend this exclusive territory through song, display, and agonistic behavior. By contrast, home range is the larger area traversed by an individual while performing routine behaviors like foraging, bathing, mating, and raising young (Burt 1943). The entire home range is not defended and conspecifics' home ranges may overlap. Both metrics use spatial data from individuals or breeding pairs obtained through labor intensive methods, most commonly telemetry or satellite tracking. At the other extreme, some have defined a species' area requirement more loosely as the smallest habitat fragment in which that species occurs (Forman et al. 1976, Galli et al. 1976, Blake 1983). However, as Wenny et al. (1993) point out, "the presence of an individual may not indicate the presence of conspecifics, let alone a viable population."

An alternative and intermediate approach is to plot the probability of a species' occurrence across habitat patches of varying size, and consider MAR to be the patch size where occurrence reaches its maximum (Robbins 1979, Hayden et al. 1985) or $50 \%$ of the maximum (Robbins et al. 1989, Crook 2002, Fernández-Juricic 2004). These incidence functions were developed by Diamond (1975a, 1975b) in his canonical study of bird assemblages on islands in New Guinea. They follow from the conceptual framework of island biogeography, in which MacArthur and Wilson (1967) proposed that species richness is a function of island area and proximity to source populations. Incidence functions require only presence/apparent absence data for a species across a range of 
patch sizes and are therefore less resource- and time-intensive than the aforementioned approaches.

I used point counts and audio broadcasts to survey woodpeckers in forest patches throughout Portland, Oregon, to predict the probability of occurrence of woodpecker species at patches of different sizes. MAR were defined as the patch size at which the predicted probability of occurrence $(P)$ reached 0.5 . A more conservative estimate was calculated at $P=0.75$. I also explored the possibility that a network of small forest patches (which, in and of themselves, would be insufficient) could be used by areasensitive species to fulfill their spatial requirements. I addressed this several-small-vs.single-large question by calculating the number of smaller patches that would be required to achieve the same probability of detecting a woodpecker as at a patch corresponding to its MAR.

\section{Methods}

\section{Study area}

Portland $\left(45^{\circ} 31^{\prime} \mathrm{N}, 122^{\circ} 40^{\prime} \mathrm{W}\right)$ covers $376 \mathrm{~km}^{2}$ and is surrounded by extensive urban development in the greater Portland metropolitan area $\left(17,300 \mathrm{~km}^{2}\right)$. Tree canopy covers $31 \%$ of the city of Portland, with many trees found in residential areas (Portland Parks \& Recreation 2017). A total of 279 parks and natural areas comprise over 4,000 ha and are irregularly distributed throughout an otherwise dense urban matrix. Portland is a large, rapidly growing city with a wide range of forest patch sizes, making it particularly relevant for studying urban woodpecker biogeography. 


\section{Patch selection}

Thirty-six forest patches were selected to characterize the range of available forest types and patch sizes found throughout the city (Figure 3.1, Table 3.1). All patches were public natural areas, urban parks, or greenspaces with $>50 \%$ canopy closure. Patch selection was performed in conjunction with biologists at the City of Portland to ensure that a representative array of patches was chosen. Patch boundaries were delineated in ArcGIS based on areas with canopy closure. Roads, urban development, and open fields and water were excluded. Forest patches ranged in size from 0.87-1337 ha, and encompassed a variety of habitat types including broadleaf riparian woodlands and upland mixedconifer forests.

Each patch contained between 1 and 6 woodpecker survey stations. The number of stations per patch was proportional to forest patch size on a logarithmic scale, which Murphy et al. (unpublished data) found to be robust. Stations were established randomly in ArcGIS, such that the minimum distance was $200 \mathrm{~m}$ between points and $100 \mathrm{~m}$ from the patch edge whenever possible (Setterington et al. 2000). This minimized the likelihood of double counting birds or detecting birds outside of the boundary.

\section{Woodpecker surveys}

Three surveys were conducted at most patches, with one survey each in April, May, and June. Twenty-six patches were surveyed in 2015, and 10 more were added in 2016 to increase sample size. To test for temporal variation between survey years a semi-random subset $(n=8)$ of the initial 26 patches were revisited twice in 2016, ensuring that 2 
patches in each of the following categories were selected: small and large broadleaf forests, and small and large conifer forests. Therefore, some patches were visited a total of five times. Paired t-tests were used to compare woodpecker occupancy and abundance between years. Abundances did not differ between years $(p<0.05)$ and therefore I analyzed all 36 patches together without regard to survey year.

Woodpeckers were surveyed at each station using variable circular-plot point counts and audio broadcast surveys (Kumar and Singh 2010). All surveys occurred between sunrise and 1000 on days without heavy rain or wind. A three-minute passive point count was conducted, followed by a sequence of audio broadcasts for five species (Downy Woodpecker [Picoides pubescens], Hairy Woodpecker, Red-breasted Sapsucker [Sphyrapicus ruber], Northern Flicker [Colaptes auratus], and Pileated Woodpecker). The call and drum of each species were broadcast twice-once facing due north and once due south-with a 30 s pause between broadcasts. The broadcast sequence was conducted in order of species' body size from small-to-large (Quayle and Westereng 1999) and the speaker volume was set to avoid overlap between survey stations. All woodpeckers seen or heard within the patch boundary were identified to species, sex and age, and distance to each individual was measured using a rangefinder in accordance with standard distance sampling methodology (Buckland et al. 2001). Any suspected case of double counting was treated as a single record. 


\section{Statistical analysis}

I measured woodpecker occurrence as the proportion of visits to a forest patch in which the species was detected. This metric reflects the frequency of occurrence at a given patch (Gaston and He 2011). I built logistic regression models (Cox 1970) in R 3.2.3 for each species to examine the relationship between patch size $(x)$ and frequency of occurrence $(y)$. In this analysis, the dependent variable was 0 if the species was never detected, 1 if detected at all visits, or assumed intermediate values reflecting actual frequency of occurrence (i.e., 0.66 when present at 2 of 3 visits). Patch size (ha) was logtransformed before analyses.

The predicted probabilities of occurrence generated by the logistic regression models were plotted against forest patch size for each species. I defined urban MAR as the patch size at which the probability of occurrence reached 0.5 (50\%) (Robbins et al 1989, Fernández-Juricic 2004). Although Robbins et al (1989) took 50 \% of maximum occurrence to be their estimate for MAR, all five woodpecker species in my study reached probabilities of occurrence $>0.96$ at the largest forest patches, so I considered patch sizes corresponding to a probability of 0.5 to be a reasonable estimate of their MAR. Because the replicates in my study are repeated visits to the same patches, my MAR represent the minimum amount of forest habitat used by one or more individuals $\geq$ $50 \%$ of the time (J. Marzluff, pers. comm.). The frequent use of forest patches of this size suggests that they are important, if not sufficient, to support the species in a fragmented urban landscape. I also calculated patch sizes where probability of occurrence reached 0.75 , and offer these are a more conservative estimate of a species' MAR. 
I regressed my estimated MAR for each species against woodpecker body mass to explore the role that body size played in predicting a species spatial requirements. Leastsquared linear regressions were used. Northern Flickers were excluded from the analysis because they represented a notable outlier, likely associated with their unique ground foraging behavior.

To address the possibility that several small patches could approximate the functional value of one large forest tract for species with substantial ( $>10$ ha) area requirements, I calculated the number $(n)$ of 1 ha and 10 ha patches that would be required for the species to occur as often as at the patch size where its probability of occurrence reached 0.5 using the following formula (see Robbins et al. 1989):

$$
\begin{gathered}
n=\frac{\log (1-0.5)}{\log \left(1-P_{x}\right)} \\
P_{x}=\text { probability of occurrence in forest patches of size } x(1 \text { or } 10) \text { ha. }
\end{gathered}
$$

\section{Results}

\section{Woodpecker occurrence}

A total of 1321 woodpecker observations were made during the surveys, resulting in an estimate of 344 individual birds throughout the study area. Northern Flickers were present at every patch and nearly every visit, while Downy Woodpeckers were present at every patch except two (Table 3.2). Red-breasted Sapsuckers were detected at the majority of patches (Table 3.2), whereas Hairy and Pileated woodpeckers were absent from the smallest patches, but were present $100 \%$ of the time (i.e. every visit) in all 
patches greater than 164 ha and 244 ha, respectively. These two species showed similar distribution through the landscape. Pileated Woodpeckers had the lowest occupancy level, being present at only 19 (53\%) of the forest patches (Table 3.2).

\section{Minimum area requirements}

The relationships between forest patch size and the predicted probabilities of occurrence generated by the logistic regressions (Table 3.3) are shown for all woodpecker species in Figure 3.2, along with MAR estimates (see also Table 3.4). The predicted probability of occurrence increased with forest area for all woodpeckers, but was most dramatic for Hairy and Pileated woodpeckers. This pair of species rarely occurred in smaller patches and neither reached their maximum occurrence until the largest forest patches were sampled (Figure 3.2). Hairy and Pileated woodpeckers had the largest MAR (34 and 51 ha, respectively), and because I defined MAR as the patch size where the probability of occurrence reached 0.5 , the odds of detecting a Hairy or Pileated woodpecker in patches below 34 ha and 51 ha, respectively, was less than $50 \%$. By contrast, the predicted probability of occurrence neared 1.0 for both species in patches over 800 ha and, in fact, both were present during all visits to every forest $>244$ ha (Figure 3.2).

The MAR of Red-breasted Sapsuckers was intermediate, but at $\sim 8$ ha (Table 3.4) suggested that they required fairly large spaces in an urban environment for a high likelihood of occurrence. However, there appear to be ample forest patches in the City of Portland capable of holding Red-breasted Sapsuckers $\geq 50 \%$ of the time. Eighty-one percent of the patches I surveyed exceeded their MAR. Estimated MAR approached zero 
for Downy Woodpeckers and especially Northern Flickers (Table 3.4). Only one park I surveyed was smaller than the estimated MAR for Downy Woodpeckers (1.31 ha). Northern flickers had a MAR of 0.6 ha, which is less than the smallest forest patch I sampled. Therefore, their probability of occurrence was $>0.5$ in every forest patch included in this study.

Several small vs. single large

Pileated and Hairy woodpeckers were the only species whose MAR exceeded 10 ha. As with most area-sensitive species, their probability of occurrence increased dramatically with patch size, so many small patches would have to be surveyed to detect an individual as often as at a single large patch. Although caution must be used in assuming that four 10 ha forest fragments would have the same ecological impact as one 40-ha fragment, my results suggest that to reach a 0.5 probability of occurrence in a landscape of small- ( 1 ha) and medium-sized (10 ha) fragments, both species would need access to roughly 40 and 4 of such fragments, respectively (Table 3.5).

\section{Discussion}

Documenting MAR of different species, and understanding why area-requirements differ among species, is of paramount conservation concern because MAR represent an approximation of the habitat size needed to maintain viable populations in any given landscape (Crooks 2002). Although the exact relationship is unstudied, it is safe to assume that MAR relate directly to territory or home range size, both of which are well- 
known to be influenced by body size as well as diet and foraging behavior (McNab 1963, Schoener 1968, Peters and Wassenberg 1983). Hence, understanding variation in MAR among woodpecker species must be viewed in the context of differences in body size and foraging behavior. It may also be the case that highly fragmented habitats, such as those found in urban environments, will influence species' MAR. In such environments it may be necessary for some individuals to move among suitable habitats embedded in an otherwise inhospitable landscape to secure the space needed to acquire sufficient resources for reproduction and survival.

The woodpecker species in this study varied over an order of magnitude in body size and substantially in foraging behavior. Downy, Hairy, and Pileated woodpeckers, and Red-breasted Sapsuckers are all primarily bark foragers (Marshall et al. 2006). The three former species extract subsurface invertebrates, while sapsuckers excavate wells to obtain tree sap and the insects attracted to it (Rodewald 2015). Northern Flickers are primarily ground foragers that specialize on ants (Marshall et al. 2006, Rodewald 2015), and are therefore the least dependent on trees for foraging. This low dependence on trees likely explains why they have the smallest MAR (Table 3.4), especially when examined in relation to body size (Figure 3.3).

MAR of other woodpeckers increased steadily with body size (Figure 3.3), and at 51 ha (or 148 ha if the more conservative estimate is used), Pileated Woodpeckers exhibited the most pronounced area sensitivity of all species (Figure 3.2). Previous measurements of territory size for Pileated Woodpeckers ranged from 130 to 549 ha (Mannan 1984), and home ranges ranged from 267 to 1,056 ha in rural Oregon forests 
(Mellen et al. 1992). Robbins et al. (1989) estimated a MAR of 165 ha for the species in remote forests in eastern North America using my same methodology, yet I regularly observed Pileated Woodpeckers in urban forest patches ranging from 24 to 164 ha. This suggests that they have adapted to a forest-limited landscape by being more flexible in their breeding and foraging ecology than previously thought. This may, in part, be explained by the fact that forests in mesic portions of the Pacific Northwest are especially productive (Huston and Wolverton 2009) and able to support higher densities of consumers, or more likely, that Pileated Woodpeckers move among fragments to stitch together sufficient space. Nonetheless, even if their home ranges are smaller than found in rural forests, they were still mostly restricted to the largest available forest patches within the urban landscape. Large-bodied species (Gaston and Blackburn 1995), especially high-level consumers (Crook 2002, Sigel et al. 2010), are typically the first species lost from highly fragmented landscapes, and thus preservation of the largest forest patches is critical for the persistence of Pileated Woodpeckers in urban spaces. What remains unclear, and in need of immediate study, is whether breeding pairs of Pileated Woodpeckers incorporate multiple forest fragments into a single home range that permits successful reproduction.

Hairy Woodpeckers also exhibited marked area sensitivity with an estimated MAR of 34 ha in urban parks. Moreover, they had the largest MAR relative to body size (Figure 3.3). Robbins et al. (1989) established a MAR for Hairy Woodpeckers of only 7 ha in rural forests in the eastern U.S., but their sample size was small as the predicted probability of occurrence never exceeded 0.27 , indicating that the species was not 
frequently detected during their surveys. Use of audio playback may have increased my ability to detect this forest-dependent species. It is also possible that internal habitat differences between the two study areas accounted for the discrepancy in detections and estimated area requirements. Hairy Woodpeckers were present at $64 \%$ of the patches I visited, and they reached nearly $100 \%$ occurrence in the largest forest patches. Hairy and Pileated woodpeckers also exhibited surprisingly large overlap in distribution; there were only four parks where one was found without the other. Why Hairy Woodpeckers have such large MAR relative to their body size is unclear and in need of further study.

The small MAR of Downy Woodpeckers and Northern Flickers may suggest that neither is area-sensitive and that both would persist in the urban landscape even if most medium- to large-sized patches were absent. However, I suspect that this is a debatable conclusion given that the probability of occurrence (Figure 3.2) and the abundance of both species increased with area (see Chapter 2). The presence of both species in small fragments, while encouraging, yields no information on whether either species would persist in small patches without the presence of woodpeckers in larger fragments that are likely to function as source populations. Stronger concerns apply to Red-breasted Sapsuckers, which exhibited a MAR of roughly 8 ha (20 acres). However, they were present at $89 \%$ of the forest patches I surveyed, including many of the traditional urban parks, which lacked multistory vegetation, downed logs, and snags. Red-breasted Sapsuckers may be more successful in urban environments than Hairy or Pileated woodpeckers, but managing forests for the two latter species is likely to benefit all three species. 
My analysis of the number of small (1 ha) and mid-sized (10 ha) patches required to yield the same probability of woodpecker occurrence as at a single larger patch stems from the fact that forest patches smaller than a species' MAR were used by woodpeckers regularly in my observations. However, it does not necessarily follow that multiple smaller fragments have the same ecological value as a large forest. There are many other variables, such as habitat type and quality, landscape connectivity, edge effect, and anthropogenic pressure, which may influence woodpecker occupancy of certain forest patches (see Chapter 2). Woodpeckers were often present in patches smaller than their estimated MAR, but presence alone does not indicate that the patch is sufficient, in and of itself, to support a breeding pair. Many of these smaller patches were in close proximity to larger forest patches, or were located in areas with high levels of forest connectivity. Forest cover in the landscape surrounding parks was especially important as a predictor of Pileated Woodpecker abundance (Chapter 2), but may be important for other species as well, given the importance of forest cover to avian dispersal (Tremblay et al. 2009, 2011).

Individuals may use a patchwork of smaller forest fragments to comprise their home range, or have a core habitat patch supplemented with satellite foraging areas. This is especially true for larger species. It is unclear how much movement occurs among isolated forest fragments, or what types of anthropogenic development act as barriers to woodpecker activity. These questions would benefit from finer grain telemetry studies. Although the approach presented here cannot address the intricacies of patch dynamics or breeding territory size, as may be possible with telemetry-based studies, I am confident 
that forest patches equaling the MAR for each species have real ecological significance. The MAR generated here represent reasonable conservation benchmarks and should be used as such.

\section{Conclusion}

Forest patches experiencing high use (i.e. where woodpeckers are found $\geq 50 \%$ of the time) constitute places of critical importance and are probably integral to sustaining viable local populations of woodpeckers. Given the strong correlation between woodpecker diversity and abundance and the diversity of other birds (Drever and Martin 2010), entire avian communities would likely benefit from the presence of such forest patches. My findings suggest that patch size is particularly important to area-sensitive species such as Pileated and Hairy woodpeckers, whose foraging, breeding, and dispersal activities may be limited by urban matrix effects. If conservation of these species is to be an objective in the face of increasing rates of urbanization, urban planners and park managers should prioritize the creation of large forested parks. I suggest that contiguous forest patches $>50$ ha be set aside to benefit woodpeckers in urban landscapes. Patches of approximately this size meet or exceed the MAR of all five woodpecker species, and I found no evidence that larger patches would have adverse affects on woodpecker occupancy. It should be emphasized that this is a minimum forest patch size. Providing forest patches $>150$ ha would increase the probability of woodpecker occurrence substantially (by 50-100\%, depending on species). Therefore, the clear recommendation would be to set $>150$ ha forests as a management benchmark, with $>50$ ha patches as a 
reasonable compromise if conserving larger patches is not possible due to various constraints. 
Table 3.1: Range of forest patches surveyed for woodpeckers in Portland, OR during the 2015 and 2016 breeding seasons.

\begin{tabular}{|c|c|}
\hline Patch Name & Area (ha) \\
\hline Midland Park & 0.87 \\
\hline Hamilton Park & 1.39 \\
\hline Kenilworth Park & 2.33 \\
\hline Columbia Boulevard Wastewater Treatment Plant & 3.35 \\
\hline John Luby City Park & 4.18 \\
\hline Whitaker Ponds & 5.12 \\
\hline Kerr Park & 5.43 \\
\hline Columbia Park & 8.43 \\
\hline Dickinson Park & 9.11 \\
\hline Catkin Marsh & 9.33 \\
\hline Johnson Lake & 9.52 \\
\hline Maricara Park & 11.23 \\
\hline Laurelhurst Park & 11.24 \\
\hline Big Four Corners North & 12.47 \\
\hline Ramsey Lake Natural Area & 16.08 \\
\hline The Grotto & 21.31 \\
\hline Company Lake & 23.71 \\
\hline Woods Memorial Park & 23.86 \\
\hline Pier Park & 24.01 \\
\hline Big Four Corners South & 25.16 \\
\hline Kelley Point Park & 32.89 \\
\hline Kelly Butte & 35.11 \\
\hline Marshall Park & 36.01 \\
\hline Oaks Bottom Wildlife Refuge & 45.72 \\
\hline Mount Tabor & 46.90 \\
\hline Hoyt Arboretum & 47.70 \\
\hline Smith and Bybee Lakes & 75.99 \\
\hline Riverview Natural Area & 82.59 \\
\hline Marquam Park & 93.54 \\
\hline Sandy River Delta & 103.69 \\
\hline Mount Talbert & 108.14 \\
\hline Powell Butte & 137.66 \\
\hline West Hayden Island & 163.74 \\
\hline Tryon Creek State Park & 244.09 \\
\hline Forest Park North & 621.74 \\
\hline Forest Park South & 1337.27 \\
\hline
\end{tabular}


Table 3.2: Woodpecker occurrence in 36 forest patches in Portland, OR, surveyed between April and June 2015 and 2016.

\begin{tabular}{lccc}
\hline \hline Species & $\begin{array}{c}\text { Number of occupied } \\
\text { patches }(\%)^{\mathrm{a}}\end{array}$ & $\begin{array}{c}\text { Smallest occupied } \\
\text { patch (ha) }\end{array}$ & $\begin{array}{c}\text { Smallest patch (ha) } \\
\text { with 100\% occurrence }\end{array}$ \\
\hline Pileated woodpecker & $19(53 \%)$ & 5.43 & 23.71 \\
Hairy woodpecker & $23(64 \%)$ & 1.39 & 23.87 \\
Red-breasted sapsucker & $32(89 \%)$ & 1.39 & 5.43 \\
Downy woodpecker & $34(94 \%)$ & 0.87 & 3.35 \\
Northern flicker & $36(100 \%)$ & 0.87 & 3.35 \\
\hline
\end{tabular}

${ }^{\mathrm{a}}$ Percentage of 36 forest patches where each species occurred on at least one survey visit. 
Table 3.3: Outputs from logistic regression models analyzing the relationship between forest patch size and woodpecker occurrence in forest fragments throughout Portland, Oregon.

\begin{tabular}{lcccc}
\hline Species & Intercept & Slope & Std. error & Pseudo $\boldsymbol{R}^{2}$ \\
\hline Pileated Woodpecker & -4.063 & 2.378 & 0.487 & 0.374 \\
Hairy Woodpecker & -3.955 & 2.583 & 0.510 & 0.458 \\
Red-breasted Sapsucker & -2.357 & 2.678 & 0.561 & 0.477 \\
Downy Woodpecker & -0.160 & 1.372 & 0.446 & 0.187 \\
Northern Flicker & 0.321 & 1.793 & 0.623 & 0.261 \\
\hline
\end{tabular}


Table 3.4: Forest patch size at which the predicted probability of woodpecker occurrence $(P)$ reaches 0.5 and 0.75 for woodpeckers surveyed in 36 forest fragments in Portland, Oregon. I suggest that the patch size at $P=0.5$ is a sound estimate, and at $P=0.75$ is a more conservative estimate, of a species' MAR.

\begin{tabular}{lcc}
\hline Species & Patch size (ha) where $\boldsymbol{P}=\mathbf{0 . 5}$ & Patch size (ha) where $\boldsymbol{P}=\mathbf{0 . 7 5}$ \\
\hline Pileated Woodpecker & 51.17 & 148.25 \\
Hairy Woodpecker & 34.12 & 90.57 \\
Red-breasted Sapsucker & 7.60 & 19.54 \\
Downy Woodpecker & 1.31 & 8.26 \\
Northern Flicker & 0.6 & 2.7 \\
\hline
\end{tabular}


Table 3.5: Number of 1 ha and 10 ha forest patches that would be required to achieve the same probability of woodpecker occurrence $(P)$ as at the patch size where $P=0.5$.

Species with MAR $<10$ ha were not included.

\begin{tabular}{lccc}
\hline \hline Species & $\begin{array}{c}\text { Patch size (ha) where } \\
\boldsymbol{P}=\mathbf{0 . 5}\end{array}$ & $\begin{array}{c}\text { Number of 1 ha } \\
\text { patches }\end{array}$ & $\begin{array}{c}\text { Number of 10 ha } \\
\text { patches }\end{array}$ \\
\hline Pileated Woodpecker & 51.17 & 40.43 & 4.09 \\
Hairy Woodpecker & 34.12 & 36.13 & 3.07 \\
\hline
\end{tabular}




\section{Figure Legends}

Figure 3.1: Map of the study area showing the distribution of 36 forest patches surveyed for woodpeckers in Portland, Oregon during the 2015 and 2016 breeding seasons.

Figure 3.2: Probability of occurrence and minimum area requirements of five woodpecker species in urban forest patches in Portland, Oregon. The black dots indicate the original data points, from which logistic regression models were constructed. The red curves indicate the predicted probabilities of occurrence generated by the logistic regressions. The dashed lines indicate the minimum area requirements for each species, defined as the patch size where the probability of occurrence reaches 0.5 .

Figure 3.3: Relationship between mean body mass and minimum area requirements based on 0.5 probability of occurrence and 0.75 probability of occurrence for five woodpecker species surveyed in forest patches throughout Portland, Oregon during the 2015 and 2016 breeding seasons. Dots correspond to each woodpecker species, from leftto-right: Downy Woodpecker, Red-breasted Sapsucker, Hairy Woodpecker, Northern Flicker, Pileated Woodpecker. The red lines are linear regression lines. Northern Flickers (hollow dot, fourth from the left) have substantially smaller, and Hairy Woodpeckers (third dot from the left) have larger, area-requirements based on body size than would be expected. Because Northern Flickers have disproportionately small area requirements and exhibit divergent foraging behavior, they were excluded from the linear regressions. 


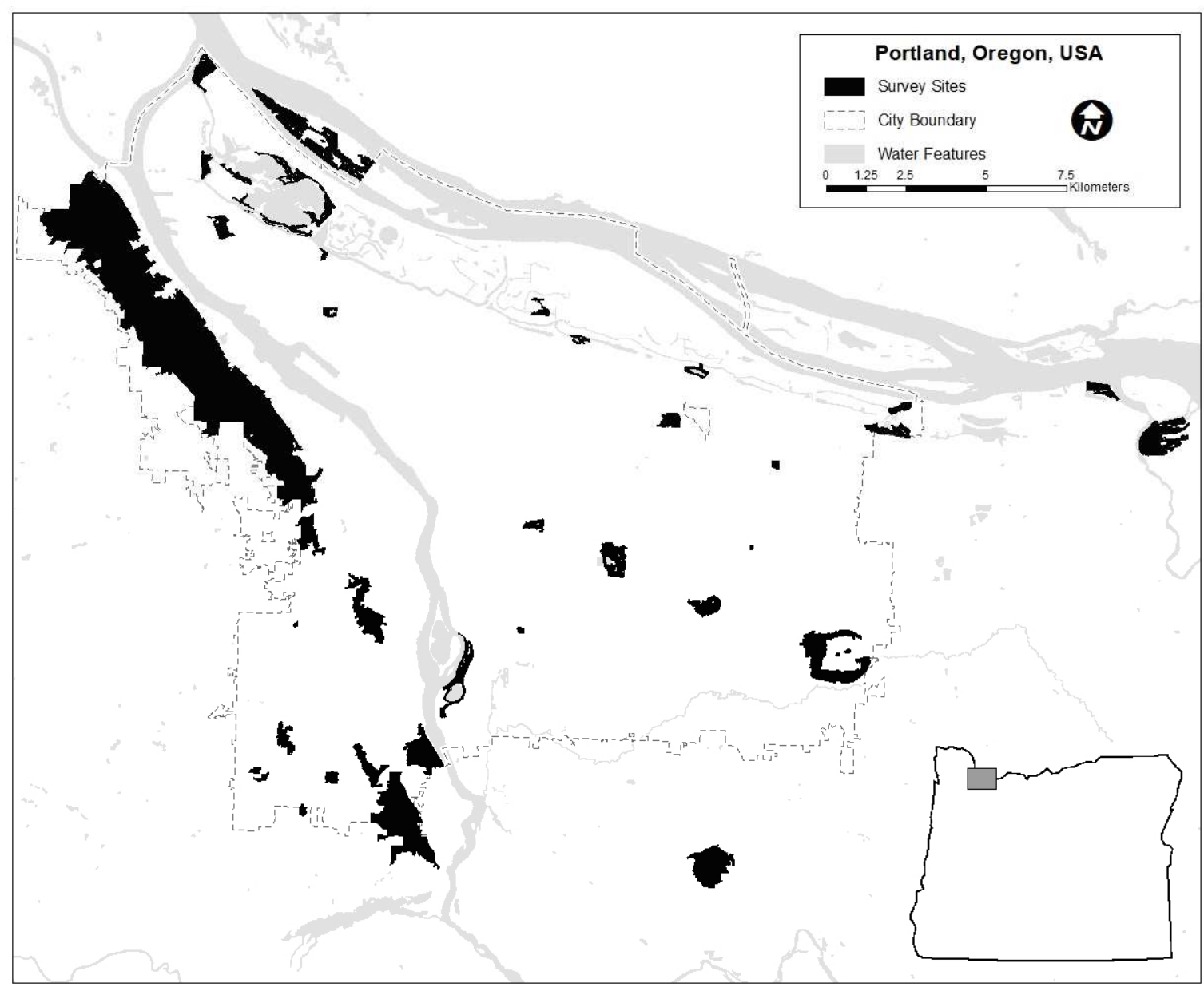

Figure 3.1 
Pileated Woodpecker

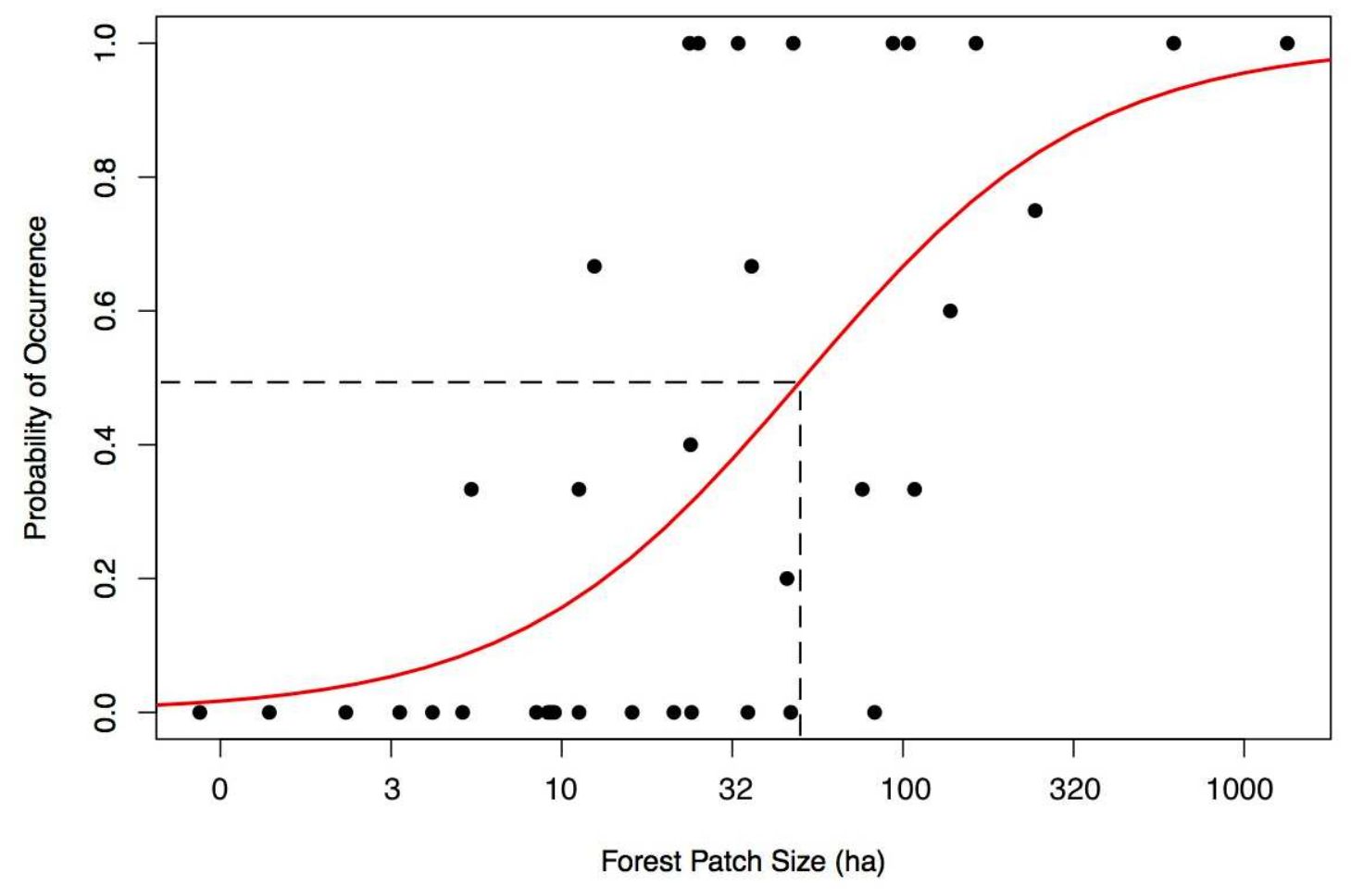


Hairy Woodpecker

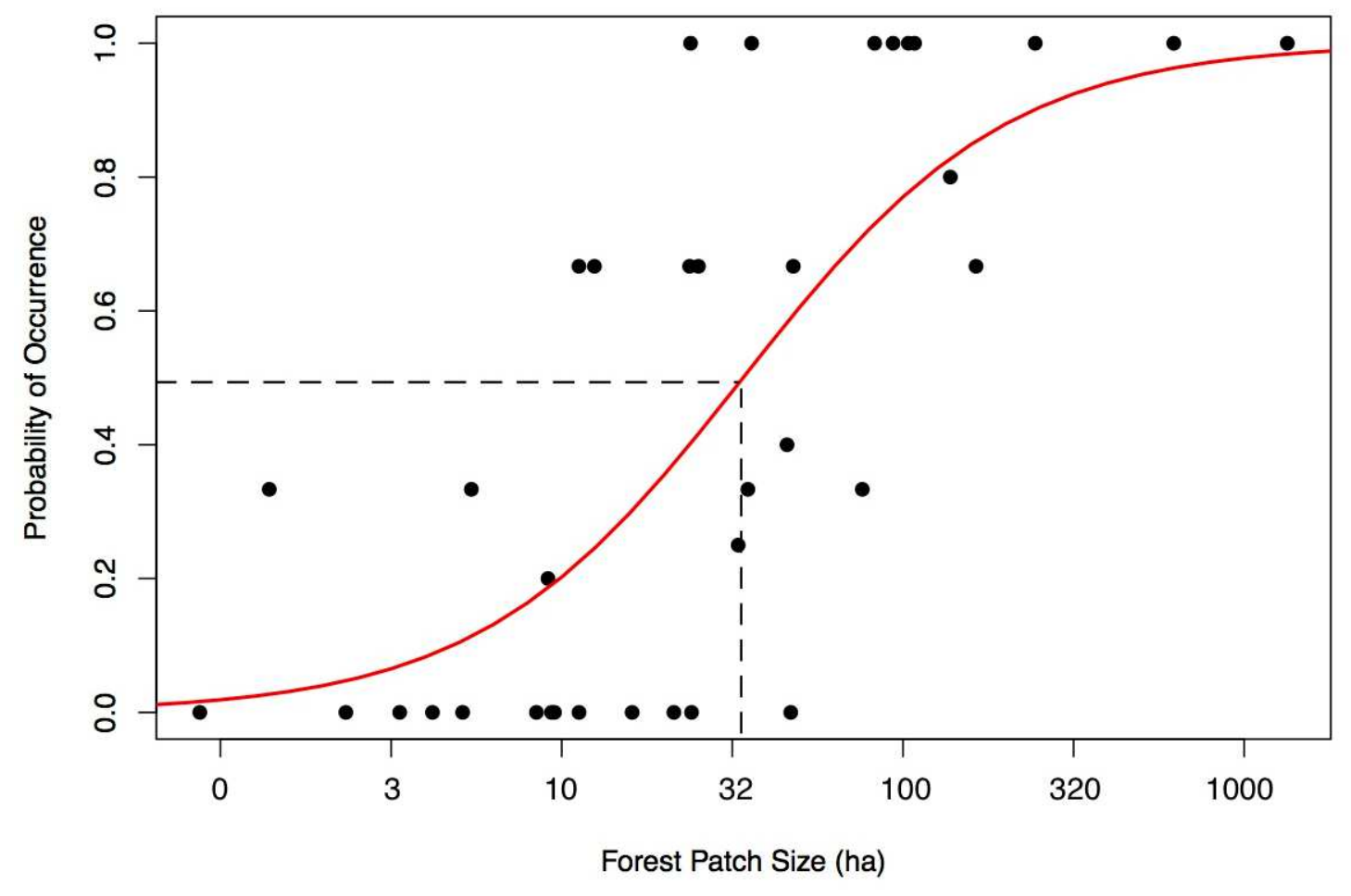


Red-Breasted sapsucker

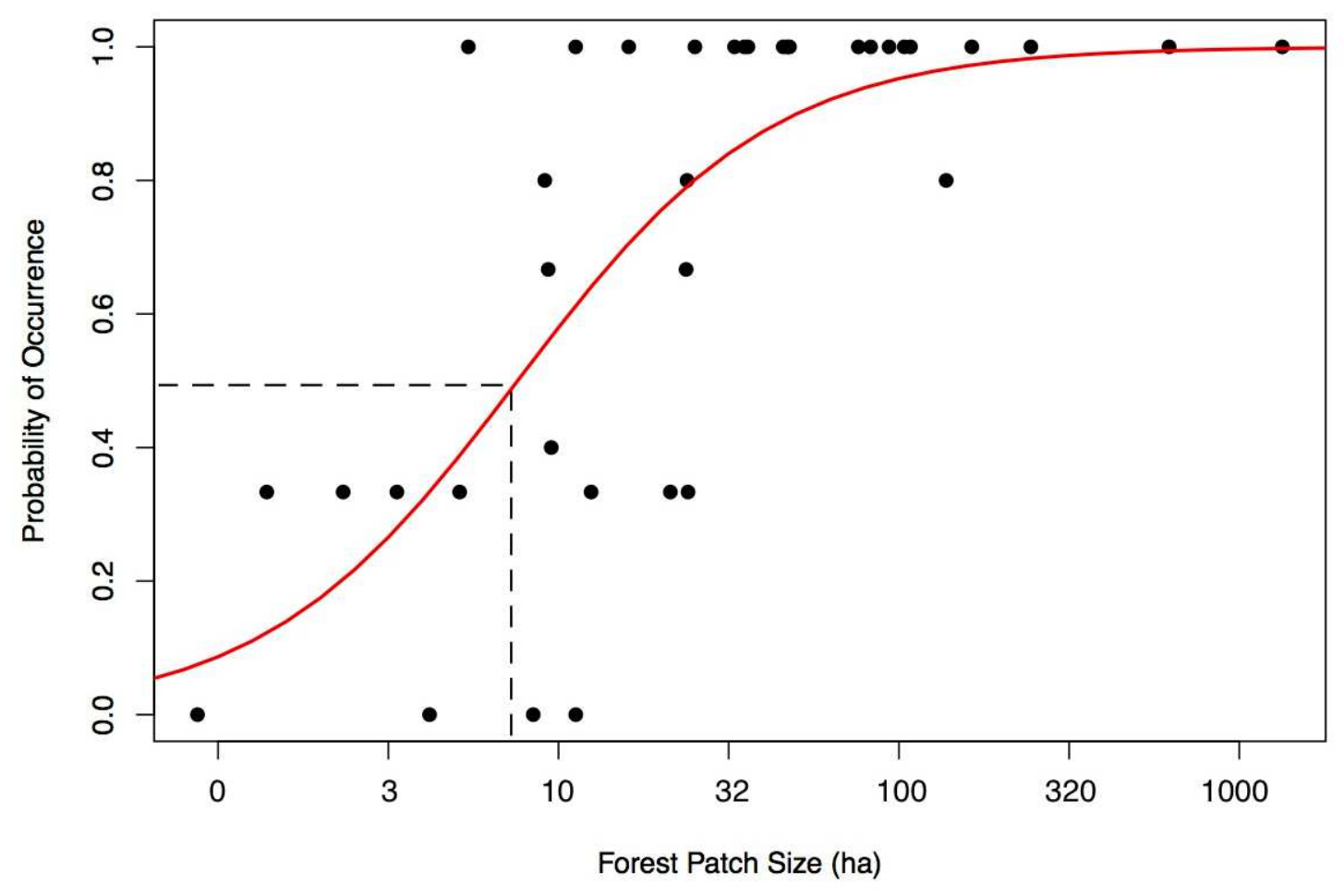




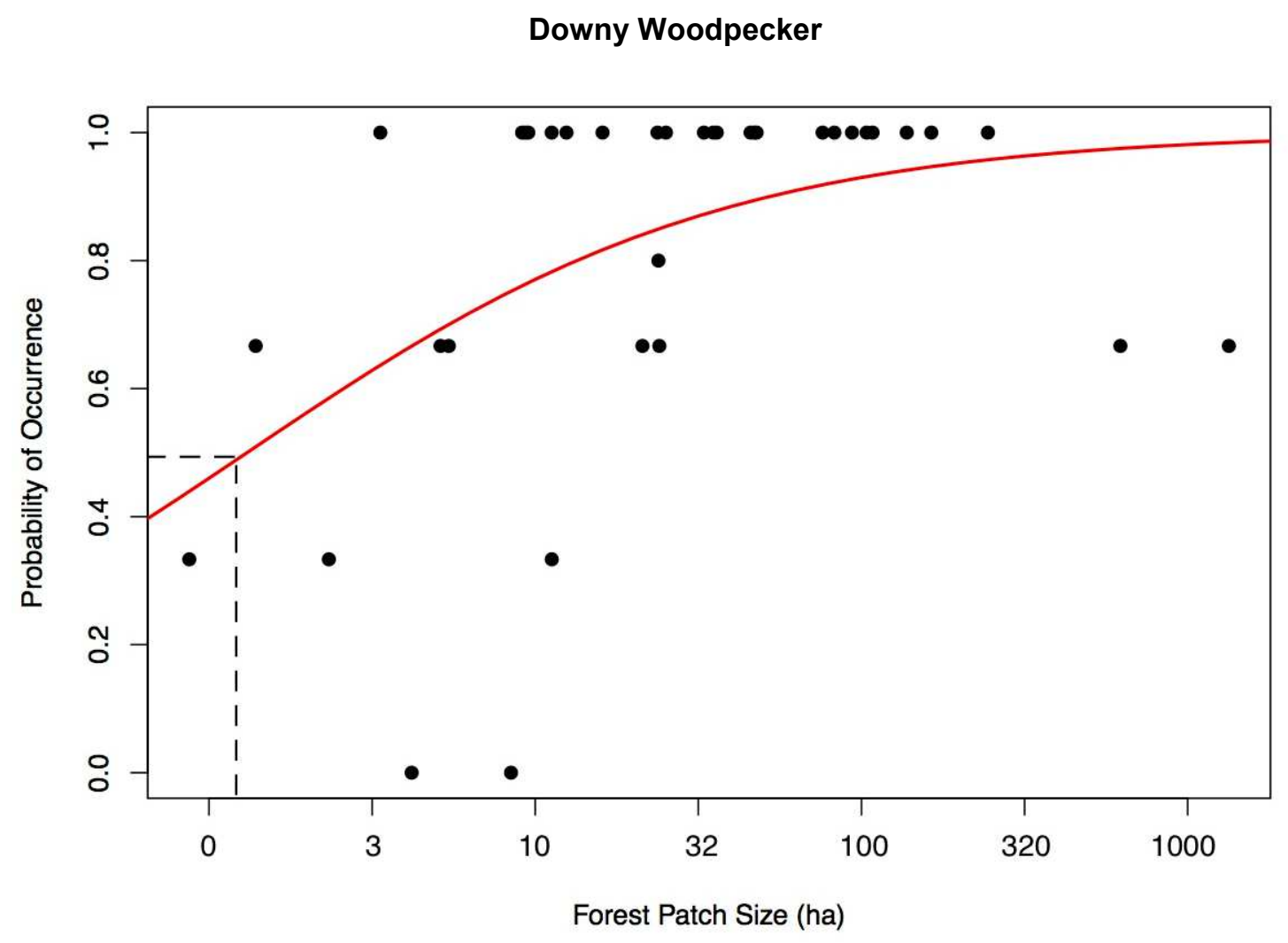




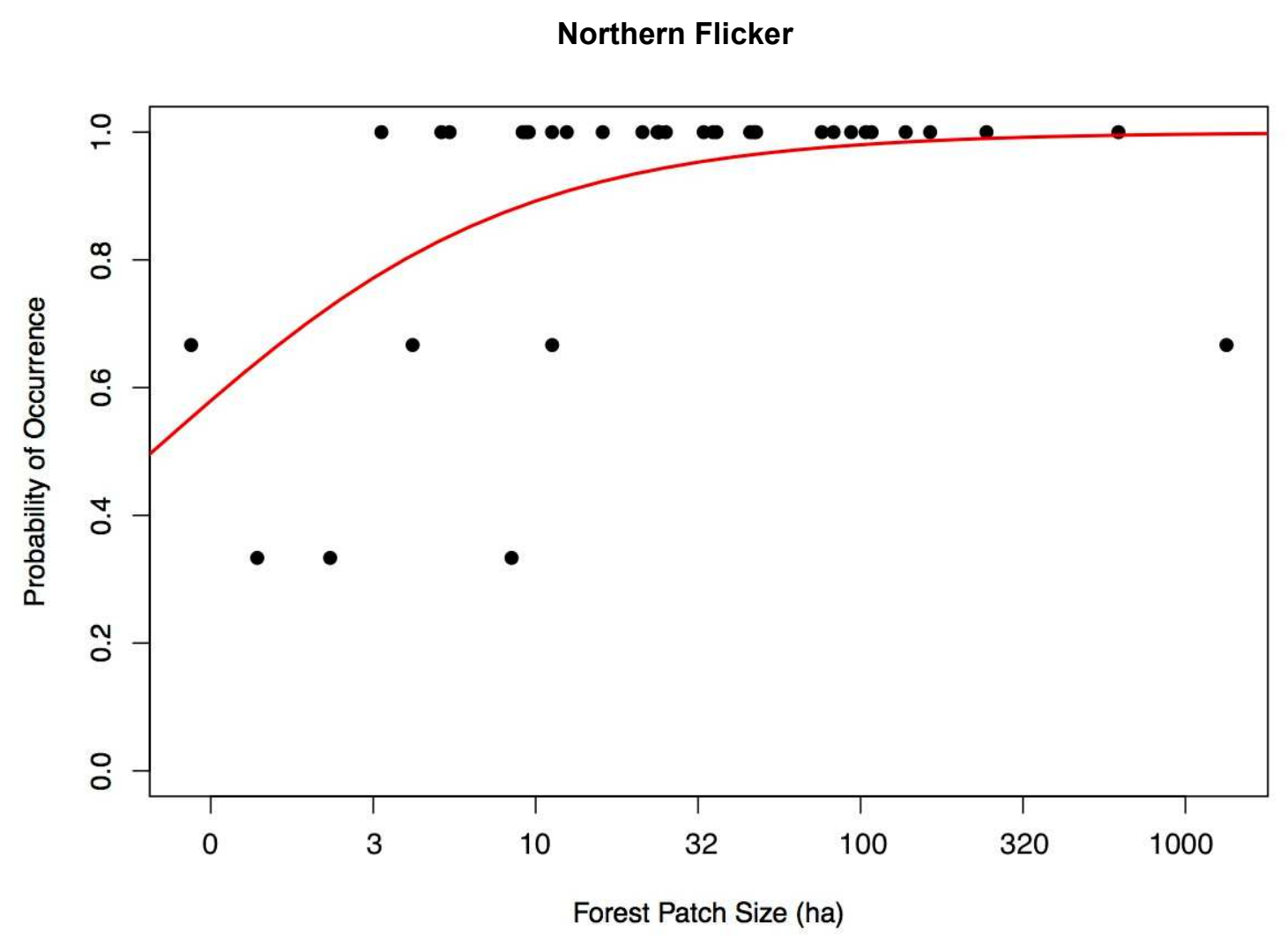

Figure 3.2 

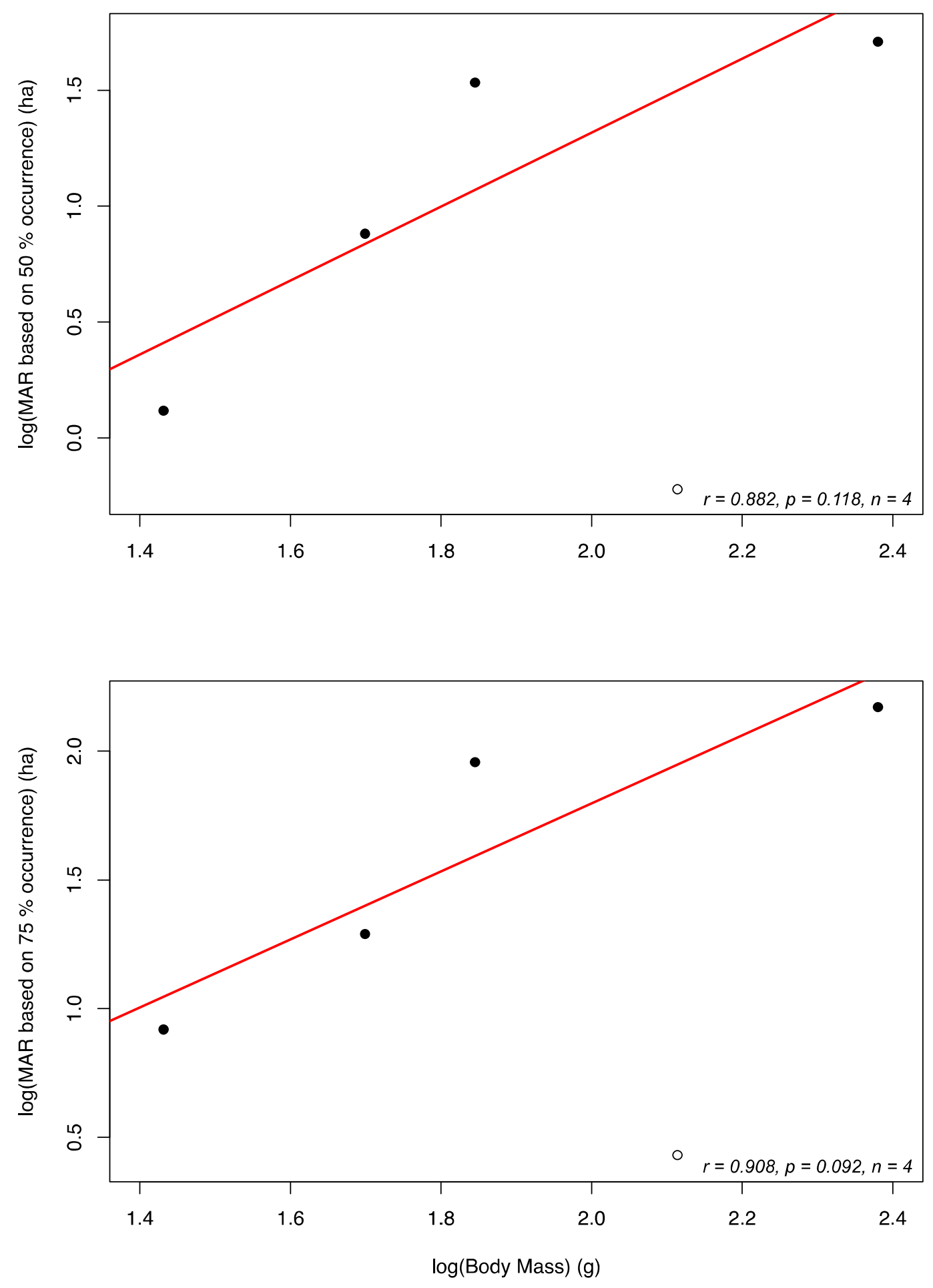

Figure 3.3 


\section{CHAPTER 4: FINAL CONCLUSIONS}

The findings presented here corroborate much of the data currently available on woodpecker populations in remote forests, while also suggesting that woodpeckers can and do behave differently in fragmented urban landscapes. Specifically, habitat use seems to be quite similar in these two types of landscapes. The habitat conditions that woodpeckers depend on in remote forest fragments are largely reflected in the data I collected in urban forest fragments. As a guild, woodpeckers appear to benefit from large, contiguous forest patches with multistory vegetation and heavy canopy closure. The percentage share of deciduous tree species and the availability of downed logs may also be of secondary importance to many woodpeckers. The most surprising finding in my research is that snag availability was not strongly correlated with woodpecker abundance. As discussed in Chapter 2, I suspect that this was a result of snags being under-sampled in my methodology, and not an ecologically meaningful revelation about woodpecker habitat associations. It is likely that snags are a critical feature for urban-dwelling woodpeckers, although supplemental feeding of suet and birdseed may diversify the foraging options for these woodpeckers, thereby reducing their dependence on insectinfected wood.

Where woodpeckers in urban areas seem to differ from their rural counterparts is in their spatial requirements. By comparing my findings with those found in current literature, I demonstrated that urban woodpeckers occur more frequently in smaller forest patches than they do in remote forests. This suggests that woodpeckers are somewhat 
flexible in their spatial footprints, and can adapt to forest-limited environments, providing that minimum amounts of adequate habitat are available. Nevertheless, natural resource managers in urban landscapes should prioritize the designation of the largest habitat patches possible. Doing so will improve the odds of sustaining local woodpecker populations and support the many species associated with woodpecker occurrence.

There are many unanswered questions about how woodpeckers use fragmented urban landscapes, and my findings on minimum area requirements elicit more questions still. Most notably, the patch dynamics and local movement patterns of woodpeckers across the urban landscape are understudied. Do woodpeckers utilize a core territory that may be too small, in and of itself, to support a breeding pair, and supplement that core area with satellite foraging patches? Or do they simply make do with substantially smaller territories than they would in more spacious remote forests? To what extent are urban-dwelling woodpeckers willing to traverse the urban matrix, and what anthropogenic features act as biological barriers? Do woodpeckers in forest-limited landscapes require a nearby source population, or are local populations self-sustainable? These questions are particularly relevant to area-sensitive species like Pileated and Hairy woodpeckers, which are undoubtedly limited by deforested landscapes. Future research should address these topics so that we can better manage our urban forests. The need for such data is increasingly critical as rates of urbanization and deforestation continue to climb. 


\section{REFERENCES}

Ahlén, I. (1975). Forestry and the bird fauna in Sweden. Ornis Fennica 52:39-44.

Andrén, H. (1994). Effects of Habitat Fragmentation on Birds and Mammals in Landscapes with Different Proportions of Suitable Habitat: A Review. Oikos 71(3): 355-366.

Angelstam, P. (1990). Factors determining the composition and persistence of local woodpecker assemblages in taiga forest in Sweden: A case for landscape ecological studies. In A. Carlson, and G. Aulén, editors. Conservation and Management of Woodpecker Populations. Report 17. Department of Wildlife Ecology, Swedish University of Agricultural Sciences, Uppsala, pp. 147-164.

Aubry, K. B. and C. M. Raley (2002). The pileated woodpecker as a keystone habitat modifier in the Pacific northwest. USDA Forest Service General Technical Report PSW-GTR-181.

Beer, J., Frenzel, L., and N. Hansen (1956). Minimum space requirements of some nesting passerine birds. The Wilson Bulletin 68:200-209.

Betts, M. G., Simon, N. P., and J. J. Nocera (2005). Point count summary statistics differently predict reproductive activity in bird-habitat relationship studies. Journal of Ornithology 146:151-159.

Bräuniger, C., Knapp, S., Kuhn, I., and S. Klotz (2010). Testing taxonomic and landscape surrogates for biodiversity in an urban setting. Landscape and Urbanization Planning 97:283-295.

Buckland, S. T., Anderson, D. R., Burnham, K. P., Laake, J. L., Borchers, D. L., and L. Thomas (2001). Introduction to Distance Sampling: Estimating Abundance of Biological Populations. Oxford University Press, Oxford, UK.

Bull, E. L., and R. S. Holthausen (1993). Habitat use and management of pileated woodpeckers in northeastern Oregon. The Journal of Wildlife Management 57:335-345.

Bull, E. L., and J. A. Jackson (1995). Pileated woodpecker (Dryocopus pileatus). In Poole, A., and F. B. Gill, editors. The Birds of North America, No. 148, The Academy of Natural Sciences, Philadelphia, PA, USA.

Burnham, K. P., and D. R. Anderson (2002). Model Selection and Multimodel Inference: A Practical Information-Theoretic Approach. Springer, NY, USA.

Burt, W. H. (1943). Territoriality and home range concepts as applied to mammals. Journal of Mammalogy. 24:346-352.

Cockle, K. L., Martin, K. and Wesołowski, T. (2011), Woodpeckers, decay, and the future of cavity】nesting vertebrate communities worldwide. Frontiers in Ecology and the Environment, 9: 377-382.

Conner, R. N., Shackelford, C. E., Saenz, D., and R. R. Schaefer (2001). Interactions between nesting Pileated Woodpeckers and Wood Ducks. The Wilson Bulletin 113:250-253. 
Cox, D. R. (1970). Analysis of Binary Data. Chapman and Hall, Ltd., London, UK.

Crook, K. R. (2002). Relative sensitivities of mammalian carnivores to habitat fragmentation. Conservation Biology 16:488-502.

Diamond, J. M. (1975a). Assembly of Species Communities. In: Diamond, J.M. and M.L. Cody, Eds. Ecology and Evolution of Communities. Harvard University Press, Boston, 342-344.

Diamond, J. M. (1975b). The island dilemma: Lessons of modern biogeographic studies for the design of natural reserves. Biological Conservation 7:129-145.

Drever, M. C., and K. Martin (2010). Response of woodpeckers to changes in forest health and harvest: Implications for conservation of avian biodiversity. Forest Ecology and Management 259:958-966.

Drever, M. C., Aitken, K. E. H., Norris, A. R., and K. Martin (2008). Woodpeckers as reliable indicators of bird richness, forest health and harvest. Biological Conservation 141:624-634.

Duncan, S. (Editor) (2003). Coming home to roost: The Pileated Woodpecker as ecosystem engineer. USDA Forest Service Science Findings No. 57.

Ellis, K. S., Larsen, R. T., Knight, R. N., and J. F. Cavitt (2014). Occupancy and detectability of Snowy Plovers in western Utah: An application to a low density population. Journal of Field Ornithology 85:355-363.

Evans, K. L., Sewson, S. E., and K. J. Gaston (2009). Habitat influences on urban avian assemblanges. Ibis 151:19-39.

Fahrig, L. (2013). Effects of habitat fragmentation on biodiversity. Annual Review of Ecology, Evolution and Systematics 34:487-515.

Farris, K. L., Huss, M. J., and S. Zack (2004). The role of foraging woodpeckers in the decomposition of Ponderosa Pine snags. The Condor 106:50-59.

Fernández-Juricic, E. (2004). Spatial and temporal analysis of the distribution of forest specialists in an urban-fragmented landscape (Madrid, Spain): Implications for local and regional bird conservation. Landscape and Urban Planning 69:17-32.

Fernández-Juricic, E., and J. Jokimäki (2001). A habitat island approach to conserving birds in urban landscapes: Case studies from southern and northern Europe. Biodiversity and Conservation 10:2023-2043.

Fitzsimons, J. A., Antos, M. J., and G. C. Palmer (2011). When more is less: Urban remnants support high bird abundance but diversity varies. Pacific Conservation Biology 17:97-109.

Forman, R. T., Galli, A. E., and C. F. Leck (1976). Forest size and avian diversity in New Jersey woodlots with some land use implications. Oecologia 26:1-8.

Galli, A. E., Leck, C. F., and R. T. Forman (1976). Avian distribution in forest islands of different sizes in central New Jersey. The Auk 93:356-364.

Gaston, K. J., and T. M. Blackburn (1995). Birds, body size, and the threat of extinction. Philosophical Transactions of the Royal Society B 347:205-212.

Gaston, K. J. and F. He (2011). Species occurrence and occupancy. In Magurran, A.E. and B.J. McGill, Eds. Biological Diversity: Frontiers in Measurement and Assessment, Oxford University Press, Oxford, UK. 
Gavareski, C. A. (1976). Relation of park size and vegetation to urban bird populations in Seattle, Washington. The Condor 78:374-382.

Growth in Urban Population Outpaces Rest of Nation, Census Bureau Reports. $<$ https://www.census.gov/newsroom/releases/archives/2010_census/cb1250.html $>$ (8 September 2014).

Haddad, N. M. et al (2015). Habitat fragmentation and its lasting impact on Earth's ecosystems. Science Advances 1:e1500052.

Hayden, T. J., Faaborg, J. and R. L. Clawson (1985). Estimates of minimum area requirements for Missouri forest birds. Transactions of the Missouri Academy of Science 19:11-22.

Huston, M. A., and S. Wolverton (2009). The global distribution of net primary production: resolving the paradox. Ecological Monographs 79:343-377.

Ikin, K., Beaty, R. M., Lindenmayer, D. B., Knight, E., Fischer, J., and A. D. Manning (2013). Pocket parks in a compact city: How do birds respond to increasing residential density? Landscape Ecology 28:45-56.

James, F. C., and H. H. Shugart, Jr. (1970). A quantitative method of habitat description. Audubon Field Notes 24:727-736.

Kang, W., Minor, E. S., Park, C.-R., and D. Lee (2015). Effects of habitat structure, human disturbance, and habitat connectivity on urban forest bird communities. Urban Ecosystems 18:857-870.

Keinath, D. A. et al (2017). A global analysis of traits predicting species sensitivity to habitat fragmentation. Global Ecology and Biogeography 16:115-127.

Kruess, A. and T. Tscharntke (1994). Habitat fragmentation, species loss, and biological control. Science 264:1581-1584.

Kumar, R., and P. Singh (2010). Determining woodpecker diversity in the sub-Himalayan forests of northern India using call playbacks. Journal of Field Ornithology $81: 215-222$.

LaMontagne, J. M., Kilgour, R. J., Anderson, E. C., and S. Magle (2015). Tree cavity availability across forest, park, and residential habitats in a highly urban area. Urban Ecosystems 18:151-167.

Lindenmayer, D. B., and J. Fischer (2006). Habitat fragmentation and landscape change: An ecological and conservation synthesis. Island Press, Washington, DC, USA.

Lorenz, T. J, et al (2015). Space use by white-headed woodpeckers and selection for recent forest disturbances. The Journal of Wildlife Management DOI:10.1002.

Maas, J., Verheij, R. A., De Vries, S., Spreeuwenberg, P., Schellevis, F. G., and P. P. Groenewegen (2009). Morbidity is related to a green living environment. Journal of Epidemiology and Community Health 63:967-973.

MacArther, R. H. and E. O. Wilson (1967). The theory of island biogeography. Princeton University Press, Princeton, NJ, USA.

MacNally, R. (2007). Use of the abundance spectrum and relative-abundance distributions to analyze assemblage change in massively altered landscapes. The American Naturalist 170:319-330. 
Mannan, R. W. (1984). Summer area requirements of pileated woodpeckers in western Oregon. Wildlife Society Bulletin 12:265-268.

Marshall, D. B., Hunter, M. G., and A. L. Contreras (Editors) (2006). Birds of Oregon: A General Reference. Oregon Statue University Press, Corvallis, OR.

Martin, K., and J. Eadie (1999). Nest webs: A community-wide approach to the management and conservation of cavity-nesting forest birds. Forest Ecology and Management 107:243-257.

Martin, K., Aitken, K. E. H., and K. L. Wiebe (2004). Nest sites and nest webs for cavitynesting communities in interior British Columbia, Canada: Nest characteristics and niche partitioning. The Condor 106:5-19.

Marzluff, J. M., and K. Ewing (2001). Restoration of fragmented landscapes for the conservation of birds: A general framework and specific recommendations of urbanizing landscapes. Restoration Ecology 9:280-292.

McNab, B. K. (1963). Bioenergetics and the determination of home range size. The American Naturalist 97:133-140.

Meffert, P. J., and F. Dziock (2013). The influence of urbanization on diversity and trait composition of birds. Landscape Ecology 28:943-957.

Mellen, T. K., Meslow, E. C., and R. W. Mannan (1992). Summertime home range and habitat use of pileated woodpeckers in western Oregon. The Journal of Wildlife Management 56:96-103.

Mikusinski, G., and P. Angelstam (1998). Economic geography, forest distribution, and woodpecker diversity in central Europe. Conservation Biology 12:200-208.

Mikusinski, G., Gromadzki, M., and P. Chylarecki (2001). Woodpeckers as indicators of forest bird diversity. Conservation Biology 15:208-217.

Mistreanu, S. (Online) (2014). The Oregonian. $<$ http://www.oregonlive.com/washingtoncounty/index.ssf/2014/06/portlandarea_population_could.html> (15 October 2014).

Morrison, J., and W. Chapman (2005). Can urban parks provide habitat for woodpeckers? Northeastern Naturalist 12:253-262.

Myczko, L., Z. M. Rosin, P. Skorka, and P. Tryjanowski (2014) Urbanization level and woodland size are major drivers of woodpecker species richness and abundance. PLOS One 9:1-10.

Nielsen, A., M. van den Bosch, S. Maruthaveeran, and C. K. van den Bosch (2014). Species richness in urban parks and its drivers: A review of empirical evidence. Urban Ecosystems 17:305-327.

Pereira, H.M. et al (2010). Scenarios for global biodiversity in the $21^{\text {st }}$ century. Science 330:1496-1501.

Peters, R. H., and K. Wassenberg (1983). The effect of body size on animal abundance. Oecologia 60:89-96.

Platt, A., and A. Lill (2006). Composition and conservation value of bird assemblages of urban 'habitat islands': Do pedestrian traffic and landscape variables exert an influence? Urban Ecosystems 9:83-97. 
Portland Parks \& Recreation (2011). Forest Park ecological prescriptions: August 2011. Portland Parks \& Recreation, Portland, OR, USA.

Portland Parks \& Recreation (2017). Tree canopy monitoring: Protocol and monitoring from 2000-2015. Portland Parks \& Recreation, Portland, OR, USA.

Quayle, J., and L. Westereng (Editors) (1999). Inventory methods for woodpeckers. MELP Resources Inventory Branch, Components of British Columbia's Biodiversity Manual No. 19.

Raphael, M. G. and M. White (1984). Use of snags by canvity-nesting birds in the Sierra Nevada. Wildlife Monographs 86:3-66.

Reynolds, R., Scott, J., and R. Nussbaum (1980). A variable circular-plot method for estimating bird numbers. The Condor 82:309-313.

Robbins, C.S. (1979). Effect of forest fragmentation on bird populations. USDA Forest Service General Technical Report. NC-51:198-212.

Robbins, C.S., Dawson, D.K., and B.A. Dowell (1989). Habitat area requirements of breeding forest birds of the middle Atlantic states. Wildlife Monographs 103:134.

Roberge, J. M. and P. Angelstam (2006). Indicator species among resident forest birds: A cross-regional evaluation in northern Europe. Biological Conservation 130:134147.

Rodewald, P. (Editor) (2015). The Birds of North America: https://birdsna.org. Cornell Laboratory of Ornithology, Ithaca, NY.

Russell, R. E., Saab, V. A., Rotella, J. J., and J. G. Dudley (2009). Detection probabilities of woodpecker nests in mixed conifer forests in Oregon. The Wilson Journal of Ornithology 121:82-88.

Saracco, J. F., Siegel, R. B., and R. L. Wilkerson (2011). Occupancy modeling of Blackbacked Woodpeckers on burned Sierra Nevada forests. Ecosphere 2:1-17.

Schielzeth, H. (2010). Simple means to improve the interpretability of regression coefficients. Methods in Ecology and Evolution 1:103-113.

Schoener, T. W. (1968). Sizes of feeding territories among birds. Ecology 49:123-141.

Setterington, M. A., Thompson, I. D., and W. A. Montevecchi (2000). Woodpecker abundance and habitat use in mature Balsam Fir forests in Newfoundland. The Journal of Wildlife Management 64:335-345.

Shackelford, C. E., and R. N. Conner (1997). Woodpecker abundance and habitat use in three forest types in eastern Texas. The Wilson Bulletin 109:614-629.

Sigel, B., W. D. Robinson, and T. W. Sherry (2010). Comparing bird community responses to forest fragmentation in two lowland Central American reserves. Biological Conservation 143:340-350.

Stralberg, D., Herzog, M. P., Nur, N., Tuxen, K. A., and Maggi Kelly (2010). Predicting avian abundance within and across tidal marshes using fine-scale vegetation and geomorphic metrics. Wetlands 30:475-487.

Strohbach, M. W., Lerman, S. B., and P. S. Warren (2013). Are small green areas enhancing bird diversity? Insights from community-driven projects in Boston. Landscape and Urban Planning 114:69-79. 
Styring, A. R., and K. Ickes (2001). Woodpecker abundance in a logged (40 years ago) vs. unlogged lowland dipterocarp forest in Peninsular Malaysia. Journal of Tropical Ecology 17:261-268.

Taylor, M. S., Wheeler, B. W., White, M. P., Economou, T., and N. J. Osborne (2015). Urban street tree density and antidepressant prescription rates: A cross-sectional study in London, UK. Landscape and Urban Planning 136:174-179.

Tremblay, M. A. and St. Clair, C. C. (2009). Factors affecting the permeability of transportation and riparian corridors to the movements of songbirds in an urban landscape. Journal of Applied Ecology, 46:1314-1322.

Tremblay, M. A. and St. Clair, C. C. (2011), Permeability of a heterogeneous urban landscape to the movements of forest songbirds. Journal of Applied Ecology, 48: 679-688.

United States Geological Survey (1998). Instructions for conducting the North American breeding bird survey. USGS Patuxent Wildlife Research Center, Laurel, MA, USA.

Wenny, D.G., Clawson, R.L., Faaborg, J. and S.L. Sheriff (1993). Population density, habitat selection and minimum area requirements of three forest-interior warblers in central Missouri. The Condor 95:968-979.

Wesolowski, T., and L. Tomialojc (1986). The breeding ecology of woodpeckers in a temperate primaeval forest: Preliminary data. Acta Ornithologica 22:1-21.

Wilson, E. O. (1975). Sociobiology: the new synthesis. Harvard University Press, Cambridge, MA.

Winkler, H., Christie, D. A., and D. Nurney (1995). Woodpeckers. Pica Press, Sussex, United Kingdom. 